\title{
Cochrane
}

Library

Cochrane Database of Systematic Reviews

\section{Care delivery and self-management strategies for children with epilepsy (Review)}

Fleeman N, Bradley PM

Fleeman N, Bradley PM.

Care delivery and self-management strategies for children with epilepsy.

Cochrane Database of Systematic Reviews 2018, Issue 3. Art. No.: CD006245.

DOI: 10.1002/14651858.CD006245.pub4.

www.cochranelibrary.com 
TABLE OF CONTENTS

ABSTRACT

PLAIN LANGUAGE SUMMARY

BACKGROUND

OBJECTIVES

METHODS

RESULTS

Figure 1.

Figure 2.

Figure 3.

DISCUSSION

AUTHORS' CONCLUSIONS

ACKNOWLEDGEMENTS

REFERENCES

CHARACTERISTICS OF STUDIES

ADDITIONAL TABLES

APPENDICES

WHAT'S NEW

HISTORY

CONTRIBUTIONS OF AUTHORS

DECLARATIONS OF INTEREST

SOURCES OF SUPPORT

DIFFERENCES BETWEEN PROTOCOL AND REVIEW

INDEX TERMS 
[Intervention Review]

\section{Care delivery and self-management strategies for children with epilepsy}

Nigel Fleeman¹, Peter M Bradley²

1Liverpool Reviews \& Implementation Group, University of Liverpool, Liverpool, UK. 2Public Health England, Cambridge, UK

Contact: Nigel Fleeman, Liverpool Reviews \& Implementation Group, University of Liverpool, 2nd Floor, Sherrington Buildings, Ashton Street, Liverpool, L69 3GE, UK. nigel.fleeman@liverpool.ac.uk.

Editorial group: Cochrane Epilepsy Group.

Publication status and date: New search for studies and content updated (no change to conclusions), published in Issue 3, 2018.

Citation: Fleeman N, Bradley PM. Care delivery and self-management strategies for children with epilepsy. Cochrane Database of Systematic Reviews 2018, Issue 3. Art. No.: CD006245. DOI: 10.1002/14651858.CD006245.pub4.

Copyright @ 2018 The Cochrane Collaboration. Published by John Wiley \& Sons, Ltd.

\section{A B S T R A C T}

\section{Background}

In response to criticism that epilepsy care for children has little impact, healthcare professionals and administrators have developed various service models and strategies to address perceived inadequacies.

\section{Objectives}

To assess the effects of any specialised or dedicated intervention for epilepsy versus usual care in children with epilepsy and in their families.

\section{Search methods}

We searched the Cochrane Epilepsy Group Specialized Register (27 September 2016), the Cochrane Central Register of Controlled Trials (CENTRAL; 2016, Issue 9) in the Cochrane Library, MEDLINE (1946 to 27 September 2016), Embase (1974 to 27 September 2016), PsycINFO (1887 to 27 September 2016) and CINAHL Plus (1937 to 27 September 2016). In addition, we also searched clinical trials registries for ongoing or recently completed trials, contacted experts in the field to seek information on unpublished and ongoing studies, checked the websites of epilepsy organisations and checked the reference lists of included studies.

\section{Selection criteria}

We included randomised controlled trials (RCTs), cohort studies or other prospective studies with a (matched or unmatched) control group (controlled before-and-after studies), or time series studies.

\section{Data collection and analysis}

We used standard methodological procedures expected by Cochrane.

\section{Main results}

Our review included six interventions reported through seven studies (of which five studies were designed as RCTs). They reported on different education and counselling programmes for children and parents; teenagers and parents; or children, adolescents and their parents. Each programme showed some benefits for the well-being of children with epilepsy, but all had methodological flaws (e.g. in one of the studies designed as an RCT, randomisation failed), no single programme was independently evaluated with different study samples and no interventions were sufficiently homogeneous enough to be included in a meta-analysis,. 


\section{Authors' conclusions}

While each of the programmes in this review showed some benefit to children with epilepsy, their impacts were extremely variable. No programme showed benefits across the full range of outcomes, and all studies had major methodological problems. At present there is insufficient evidence in favour of any single programme.

\section{PLAIN LANGUAGE SUMMARY}

\section{Care delivery and self-management strategies for children with epilepsy}

\section{Background}

Epilepsy is spectrum of disorders in which a person may have seizures (fits) that are unpredictable in frequency. Most seizures are well controlled with medicines and other types of treatments, but epilepsy can cause problems in social, school and work situations, making independent living difficult. People with seizures tend to have physical problems (e.g. fractures, bruising and a slightly increased risk of sudden death) as well as social problems because of the stigma attached to the illness. People with epilepsy and their families may lack social support or experience social isolation, embarrassment, fear and discrimination, and some parents may also feel guilty. Selfmanagement of epilepsy refers to a wide range of health behaviours and activities that a person can learn and adapt to control their seizures and improve their well-being. This approach needs a partnership between the person and the providers of services (e.g. specialist epilepsy outpatient clinics, nurse-based liaison services between family doctors and specialist hospital doctors, specialist epilepsy community teams), as well as targeted services for specific groups (e.g. children, teenagers and families).

\section{Study characteristics}

We searched scientific databases for studies in children and adolescents with epilepsy that looked at the effects of self-management of epilepsy. The results are current to September 2016. We wanted to look at several outcomes to see how well people and their families generally cope with epilepsy.

\section{Key results}

This review compared six education- or counselling-based self-management interventions for children with epilepsy. Four interventions were aimed at children and their parents; one was aimed at teenagers and their parents; and one was aimed at children, adolescents and their parents. Each of the interventions appeared to improve some of the outcomes studied, but no intervention improved all of the outcomes that were measured. The studies also had problems with their methods, which makes their results less reliable. While none of the interventions caused any harm, their impact was limited, and we cannot recommend any single intervention as being the best one for children with epilepsy.

Evidence for the best ways to care for children with epilepsy is still unclear.

\section{Quality of the evidence}

The quality of the evidence is poor because all of the studies had major problems in how they were run. 


\section{B A C K G R O U N D}

\section{Description of the condition}

Epilepsy is a spectrum of disorders in which a person may experience seizures that are unpredictable in frequency (England 2012). Researchers have identified at least 40 different seizure types (Berg 2010). While most people can control seizures with medications and other treatment options, epilepsy can pose challenges in social, school and work situations and for independent living. Not only do people with seizures tend to have more physical problems (such as fractures, bruising and a slightly increased risk of sudden death), they also face significant challenges because of how the condition is perceived (or indeed misperceived), which can lead to people with epilepsy being stigmatised (Bandstra 2008). As a result, both people with epilepsy and their families may lack social support and experience social isolation, embarrassment, fear and discrimination, while some parents also report feelings of parental guilt (England 2012). Epilepsy affects around 50 million people worldwide, with around $80 \%$ of all cases in developing countries (WHO 2012). Epilepsy is most common in children and older adults (Betts 1992; Sander 1990).

\section{Description of the intervention}

The self-management of epilepsy refers to a wide range of health behaviours and activities that a person can learn and adapt in order to promote seizure control and enhance well-being (Austin 1997). Self-management of any condition typically entails a partnership between users and service providers (Clark 2008). Various dedicated models of service provision exist to improve care networks and self-education (Clark 2010; Fitzsimons 2012; SIGN 2003; SIGN 2005). Services may include specialist epilepsy outpatient clinics, nurse-based liaison services between primary (general practitioner; GP) and secondary/tertiary (hospital-based) care, and specialist epilepsy multidisciplinary community teams (Clark 2010; Fitzsimons 2012; SIGN 2003; SIGN 2005). Services may also include input from social care or the voluntary sector and be targeted at specific groups, such as children, teenagers and the families of people with epilepsy (Clark 2010; SIGN 2003; SIGN 2005).

\section{How the intervention might work}

Specialist or dedicated models of care, care networks or selfeducation and self-management may improve the quality of care, promote more systematic multidisciplinary follow-up, and enhance communication among professionals, patients and other services (Fitzsimons 2012). Importantly, it should enable people with epilepsy (and their families) to cope with all aspects of the disease through improved self-education and self-management (Clark 2008; Fitzsimons 2012).

\section{Why it is important to do this review}

Different authors have criticised epilepsy care for its limited impact on the range of health and social needs of people with epilepsy (Betts 1992; Chappell 1992; Elwyn 2003; Thapar 1996). In order to improve the quality of care for people with epilepsy, we aimed to produce a systematic review of the evidence from studies investigating the effects of these service models compared to nonspecialist services. This systematic review is an update of the Cochrane Reviews previously published in 2010 and 2015 (Fleeman 2015; Lindsay 2010).

\section{O B JECTIVES}

To assess the effects of any specialised or dedicated intervention for epilepsy versus usual care in children with epilepsy and in their families.

\section{METHODS}

\section{Criteria for considering studies for this review Types of studies}

We included several study types in the review, as the interventions considered were highly variable and complex. The inclusion criteria for studies were based on those used by the Cochrane Effective Practice and Organisation of Care (EPOC) Group. As specified in the protocol for this review (Lindsay 2006), we included all randomised controlled trials, cohort studies or other prospective studies with a (matched or unmatched) control group (controlled before-andafter studies) or time series studies. We included studies reported only as abstracts and those described in trial registries as having an expected study completion date prior to 27 September 2016 in the Studies awaiting classification category.

\section{Types of participants}

As specified in the review protocol (Lindsay 2006), studies that included children with any diagnosis of new or recurrent epilepsy aged under 18 years were eligible for this review. We included studies incorporating epilepsy with other long-term conditions if they reported results separately for each condition.

\section{Types of interventions}

In accordance with protocol for this review (Lindsay 2006), we included any intervention involving a specialised or dedicated team or person for the care of children or adolescents with epilepsy, whether based:

- in hospital (e.g. a specialist epilepsy clinic);

- in the community (e.g. a specialist pharmacist);

- in general practice (e.g. a specialist epilepsy nurse);

- elsewhere (e.g. social worker, the voluntary sector);

- as a care network combining any of these elements;

- on education or counselling for improved self-management.

\section{Types of outcome measures}

As specified in the review protocol (Lindsay 2006),the outcome measures included:

- seizure frequency and severity;

- appropriateness and volume of medication prescribed (including evidence of drug toxicity);

- child or family's reported knowledge of information and advice received from professionals;

- child or family's reports of health and quality of life (including adverse effects of medication);

- objective measures of general health status;

- objective measures of social or psychological functioning (including the number of days spent on sick leave/absence from school and employment status);

- costs of care or treatment. 
We assessed all outcome measures for reliability and validity (i.e. for clinical relevance or whether validated tools were used for outcome measurement). If measures were misused (e.g. adults scales used on children), we would have investigated their effect on study results using a sensitivity analysis.

\section{Search methods for identification of studies}

As specified in the protocol for this review (Lindsay 2006), we searched the following databases.

- Cochrane Epilepsy Group Specialized Register (27 September 2016). See Appendix 1 for details of search strategy.

- Cochrane Central Register of Controlled Trials (CENTRAL; 2016, Issue 9) in the Cochrane Library (searched 27 September 2016). See Appendix 2 for details of search strategy.

- MEDLINE via Ovid (1946 to 27 September 2016). See Appendix 3 for details of search strategy.

- Embase (1974 to 1 November 2016). See Appendix 4 for details of search strategy.

- PsycINFO via EBSCOhost (1887 to 27 September 2016). See Appendix 5 for details of search strategy.

- CINAHL Plus via EBSCOhost (1937 to 27 September 2016). See Appendix 6 for details of search strategy.

We also searched clinical trials registries for ongoing or recently completed trials. See Appendix 7 and Appendix 8 for details of search strategy.

Finally, we contacted experts in the field to seek information on unpublished and ongoing studies, checked the websites of epilepsy organisations and checked the reference lists of included studies.

Our search strategy was the same as for a parallel review of care delivery and self-management strategies for adults with epilepsy (Bradley 2016a)

\section{Data collection and analysis}

\section{Selection of studies}

We screened papers in two stages. At stage one, two review authors (PM and BL in the original review, PM and NF in the updated reviews), independently screened all titles and abstracts of papers identified by the searches for relevance. We excluded only papers that were clearly irrelevant at this stage. At stage two, two review authors (PM and BL in the original review, PM and NF in the updated reviews) independently screened the full papers, identified relevant studies and assessed eligibility of studies for inclusion. We resolved any disagreements by discussion.

\section{Data extraction and management}

The same review authors extracted the following types of data.

- Study characteristics - place of publication, date of publication, population characteristics, setting, detailed nature of intervention, detailed nature of comparator and detailed nature of outcomes. A key purpose of these data was to define unexpected clinical heterogeneity in included studies independently from analysis of results.

- Results of included studies with respect to each of the main outcomes indicated in the review question, including data on outcomes not considered, and considering the possibility of selective reporting of results on particular outcomes.

We resolved any disagreements when extracting data by discussion. If reports provided inadequate information, we contacted authors for further information.

\section{Assessment of risk of bias in included studies}

Two review authors (NF and PB) assessed every study independently using the suggested risk of bias criteria for Cochrane Effective Practice and Organisation of Care (EPOC) reviews (Cochrane EPOC 2012). In accordance with the review protocol (Lindsay 2006), we resolved any disagreements when assessing risk of bias by discussion. If reports provided inadequate information, we contacted authors for further information.

\section{Measures of treatment effect}

We presented the measures of treatment effect as reported in the published papers. Where $P$ values were presented in the published papers, we reported $P$ values exactly as presented in the papers (including the reporting of $P$ values for non-statically significant findings where the authors reported these $P$ values). As specified in the protocol for this review (Lindsay 2006), If it had been possible to combine results in a meta-analysis, treatment effects would have been measured using (standardised) weighted mean differences for continuous variables and relative risks (including Mantel Haenzsel analysis) for dichotomous variables.

\section{Unit of analysis issues}

Where studies included multiple treatment arms, we reported data from all treatment arms. If it had been possible to combine results in a meta-analysis, where only one experimental arm was considered sufficiently similar to the experimental arm of other included studies, we would have included only the relevant experimental arm. Where more than one of the experimental arms were considered sufficiently similar to the experimental arm of other included studies, we would have either (i) combined experimental groups to make a simple pair-wise comparison; or (ii) split the control group to include more than one comparison.

\section{Dealing with missing data}

Had we discovered important data were missing that prevented us from being able to conduct a meta-analysis, we would have attempted to obtain the relevant data from study authors.

\section{Assessment of heterogeneity}

We assessed clinical heterogeneity between studies by reviewing the differences across studies. There was considerable methodological and clinical heterogeneity in the studies, so we did not consider a meta-analysis appropriate. Had we decided to combine the results of any studies in a meta-analysis, we would have investigated statistical heterogeneity using the chi-squared test for homogeneity and the 12 test statistic (Higgins 2003). If the results had shown heterogeneity, we would have investigated the cause (Higgins 2011).

\section{Assessment of reporting biases}

For all studies, we checked whether the outcomes intended to be measured (reported in the methods sections) were reported in the findings sections. If data were missing, we would have attempted 
to contact study authors. Had we included 10 studies or more in a meta-analysis an assessment of the risk of publication bias would have been conducted by constructing a funnel point and conducting a simple test of asymmetry to test for possible bias (Egger 1997).

\section{Data synthesis}

The results of the data extraction and quality assessment for each study were presented in structured tables and as a narrative summary. All summary statistics were extracted for each outcome. If studies had been of a suitable quality and sufficiently homogeneous, we would have pooled the results in a metaanalysis. A fixed-effects model would be used in the case of minimal heterogeneity and a random-effects model in the case of substantial levels of heterogeneity.

\section{Subgroup analysis and investigation of heterogeneity}

No subgroup analyses were planned a priori, with no prespecified subgroups specified in the review protocol (Lindsay 2006), Had we decided to combine the results of any studies in a metaanalysis and found evidence of statistical heterogeneity, we would have considered the conduct of post-hoc subgroup analyses where appropriate and where the data allowed (Higgins 2011).

\section{Sensitivity analysis}

For future updates of this review, if the data permit the conduct of meta-analysis, we will consider sensitivity analyses based on the risk of bias. Where we include studies with multiple experimental arms, sensitivity analyses by including different experimental arms from a particular study will be considered or, if the data allows, different approaches to meta-analysis (e.g. combining experimental groups to make a simple pair-wise comparison and/ or splitting the control group to include more than one comparison) will also be considered.

\section{RES U L T S}

\section{Description of studies}

\section{Results of the search}

In the original review, initial searches identified over 4000 papers, including duplicates, of which we included four (Glueckauf 2002; Lewis 1991; Rau 2006; Tieffenberg 2000). We identified a fifth paper, Lewis 1990, from the reference list of Lewis 1991; both of these papers reported on same intervention, but Lewis 1990 focused on the impact on children, while Lewis 1991 assessed outcomes in and parents.

The search in the 2015 update, Fleeman 2015, yielded 2438 additional papers, including duplicates, plus two studies that were awaiting assessment from the original review (Jantzen 2009; Shore 2008). We included one of these, a controlled before-and-after study, in the review update (Jantzen 2009). We also included Pfäfflin 2012, which was published after the original review. This study report by Pfäfflin 2012 evaluated the same intervention as a previously included controlled before-and-after study published in German (Rau 2006), but it also provided additional information. The additional information included was obtained from the same participants and at the same point in time. While we previously included both study reports in our review as separate studies, we have now classified these study reports as the same study, with Pfäfflin 2012 cited as the primary reference.

For this most recent update, the searches yielded 1680 additional papers including duplicates. We included only one additional study (Modi 2016).

In total, we included seven different studies reporting on six different interventions in the review: five designed as RCTs (Glueckauf 2002; Lewis 1990; Lewis 1991; Modi 2016; Tieffenberg 2000), plus two controlled before-and-after studies (Jantzen 2009; Pfäfflin 2012). Figure 1 presents the study flow chart, and Characteristics of included studies table describes study characteristics. 
Figure 1. Study flow diagram (original and updated searches).

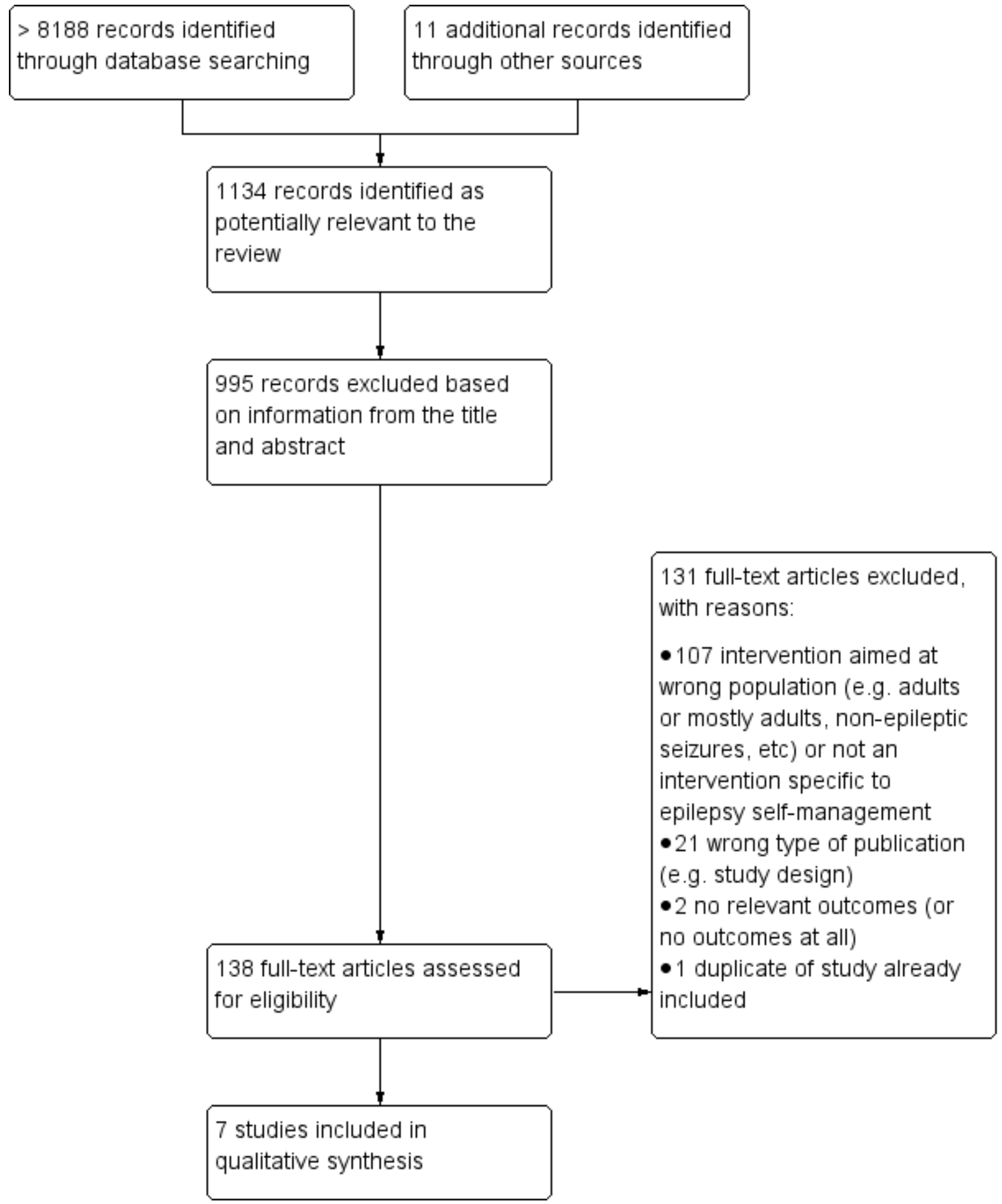

\section{Included studies}

All of the included studies investigated interventions for improved self-management (see Characteristics of included studies): these interventions consisted of education, counselling or training. No included study investigated specialist teams of health or social care professionals in hospital or community settings or as care networks. Four interventions included children and parents, one through two RCTs (Lewis 1990; Lewis 1991), one as a field trial designed as a cluster-RCT (Tieffenberg 2000) and one through 
a controlled before-and-after study (Pfäfflin 2012). Of the other studies, one involved teenagers and parents (Glueckauf 2002), and one involved children, adolescents and parents (Jantzen 2009). The studies provided varying details about the specifics of the interventions. This information is summarised in Appendix 9. With the exception of the controlled before-and-after evaluation of FAMOSES (Pfäfflin 2012), the researchers who authored the reports designed, delivered and evaluated all of the interventions. Pfäfflin 2012 was a pilot, and Glueckauf 2002 was a phase I study. Four studies reported they had previously piloted their interventions (Jantzen 2009; Lewis 1990; Lewis 1991; Modi 2016), but only the pilot feasibility study for Modi 2016 had been previously published (Modi 2013); we identified this pilot feasibility study in our searches but excluded it from the review (see Excluded studies for more information).

\section{Strategies for children and parents}

Tieffenberg 2000 reported on the effects of ACINDES, a nonepilepsy-specific model for self-management training for children with chronic conditions (children with asthma were also included) based on play techniques (see Appendix 9 for details). The model was developed by the researchers specifically for Spanishspeaking children aged 6 to 15 years. It is delivered outside of the hospital environment (by teachers, in schools, with physicians providing guidance, acting as counsellors) and includes sessions held simultaneously for parents. These sessions are meant to enable them to learn to recognise and accept their children's autonomy and become 'facilitators' rather than 'managers' in their children's disease self-management.

ACINDES was evaluated by a cluster-RCT 355 children (167 with epilepsy) in Buenos Aires, Argentina. Both children and parents were interviewed before the programme and at 6 and 12 months after its completion. In addition, medical and school records were monitored for emergency and routine visits, hospitalisations and school absenteeism. The intervention group received the ACINDES programme while children and parents in the control group received routine care without additional training.

Lewis 1990 and Lewis 1991 evaluated the Children's Epilepsy Program (CEP), a child-centred, family-focused educational programme developed at the Medical Center of the University of California in Los Angeles (UCLA) for children and their parents (see Appendix 9 for details). Following the completion of a pilot study, the researchers could not recruit a suitable sample from the UCLA Medical Center because of an insufficient number of referrals of children with epilepsy in the Los Angeles area, so the evaluation of the CEP took place in Santiago, Chile. This required translating the programme into Spanish for the trial. Lewis 1990 reported on the impact of CEP on children, and Lewis 1991 reported on the impact of CEP on parents.

The study recruited 252 children aged 7 to 14 years and 294 parents selected from 1000 families belonging to the Liga Contra Epilepsia. Families were randomly allocated in groups of 20 to the intervention and control groups. All participants were tested immediately prior to the first session and five months after the end of the CEP. The intervention groups of children $(n=123)$ and parents $(n=185)$ separately undertook CEP whereas the control groups of children $(n=113)$ and parents $(n=109)$ jointly attended three two-hour sessions consisting of lectures and question and answer discussions. Authors described the control intervention as 'passive learning' in contrast to the 'active learning' of the intervention. Only $78.6 \%$ of children in the intervention group and $52 \%$ of children in the control group attended all the required sessions (Lewis 1990); $73.2 \%$ of mothers and $59 \%$ of fathers attended all four sessions in the intervention group, and $62 \%$ of mothers and $49 \%$ of fathers attended all three sessions in the control group (Lewis 1991).

Pfäfflin 2012 reported on a prospective, controlled before-andafter, multicentre study in Germany and evaluated FAMOSES, a modular educational programme for children with epilepsy and their parents (see Appendix 9 for details). FAMOSES aims to improve knowledge, coping, treatment outcomes and adaptation to epilepsy through a series of educational modules.

Children with epilepsy, aged 7.2 to 15.9 years, were allocated along with their parents to an intervention group (children, $\mathrm{n}=$ 31 ; parents, $n=55$ ) or waiting list control group (children, $n=19$; parents, $n=48$ ). Children and parents completed questionnaires at baseline and then three months after completing FAMOSES.

Modi 2016 evaluated the Supporting Treatment Adherence Regimen (STAR). The aim of this family-tailored problem-solving intervention was to improve adherence to antiepileptic drugs (see Appendix 9 for details).

Of 50 children aged 2 to 12 years and their caregivers who agreed to participate in the study, the authors report that 45 families were eligible for randomisation. However, families were only randomised if investigators assessed adherence to antiepileptic drugs as less than $95 \%$ over the previous seven months; those with adherence of $95 \%$ or more were allocated to a maintenance 'high adherence' group. Thus, in total, 22 families were not randomised, 11 were allocated to STAR, and 12 were allocated to the treatment as usual (TAU) group. The authors hypothesised that children and families in the STAR intervention group would demonstrate significant improvements in adherence to antiepileptic drugs compared to theTAU group and maintain these effects over a 3month follow-up period.

\section{Strategies for teenagers and parents}

Glueckauf 2002 was a three-arm RCT studying the effects of a programme comparing video-conference (VFC) versus office-based counselling (OFC) for teenagers and their families based in the rural Midwest, USA (see Appendix 9 for details). The model for the intervention is based on an issue-specific family counselling model.

Thirty-nine families were recruited, but 12 dropped out before counselling and 5 more dropped out prior to six-month followup. Hence, 22 teenagers and their 36 parents were randomised as follows: 9 teenagers and their parents to VFC, 6 teenagers and their parents to OFC and 7 teenagers and their parents to waiting list control. However, not all families allocated to VFC could receive it because of a lack of digital services, so four of the nine families were instead given counselling by speaker phone (SFC), that is, randomisation failed. Investigators took baseline measures at the initial session. The participants received questionnaires after their sixth session and at six-month follow-up. Around $10 \%$ of study participants exercised their option to continue with two further sessions after the sixth session. 


\section{Strategies for children, adolescents and their parents}

Jantzen 2009 was a multicentre two-arm controlled before-andafter study in 10 specialised German epilepsy centres. Investigators compared outcomes for a waiting-list control group versus the FLIP\&FLAP programme, which used an experience-based learning approach for family and behaviour therapy including imagination techniques, elaborating resources, role play and problem-solving strategies (see Appendix 9 for more details).

Eligible participants were children aged 8 to 11 years or adolescents aged 12 to 16 years who were receiving treatment for epilepsy and, along with a parent, were willing to participate in the study. All centres offered two educational courses. Applicants for the first course were assigned to the intervention group; applicants for the second course were assigned to the waiting-list control group; the waiting-list control group then participated in the programme six months later. Assessments were performed at baseline, six months after starting the programme and six weeks after completing the programme (in both groups).

\section{Excluded studies}

We excluded one of the studies awaiting classification from the 2010 version of this review because it lacked a control group (Shore 2008). It reported a feasibility study of the Seizures and Epilepsy Education (SEE) programme. Similarly, we excluded Austin 2002 for being a pre- and post-test feasibility study lacking a control group. We excluded three other studies for having the wrong type of study design (Price 2004; Shore 2008; Snead 2004). Although Hallfahrt 2007 reported on the FLIP\&FLAP programme (in German), we confirmed by contact with the author that it did not include any new data to that reported (in English) in Jantzen 2009, and so we excluded it. See Characteristics of excluded studies table. We excluded two studies identified by the most recent update because they included a mix of adults and children with a mean age of participants over 18 years (Ibinda 2014; Li 2013). The review update of interventions for adults will include these two studies. As previously described, a small feasibility study $(n=8)$, Modi 2013, previously evaluated the intervention assessed in Modi 2016 and so this small study was also excluded.

\section{Ongoing studies and studies awaiting classification}

We identified one ongoing study, IRCT2015060122514N1, and another that was due to have been completed in 2015 (NCT02349529). We describe the study characteristics for these two trials in Ongoing studies and Studies awaiting classification, respectively.

\section{Risk of bias in included studies}

There is a potential risk of bias in all seven included studies (Glueckauf 2002; Jantzen 2009; Lewis 1990; Lewis 1991; Modi 2016; Pfäfflin 2012;Tieffenberg 2000), particularly as two studies were not randomised (Jantzen 2009; Pfäfflin 2012), and in a third, randomisation failed (Glueckauf 2002). Furthermore, it is unclear how trials allocated participants, whether they were blinded or how they accounted for dropouts. Indeed, overall, we considered three studies to be at high risk of bias (Glueckauf 2002; Jantzen 2009; Pfäfflin 2012). We did not consider any study to be at low risk of bias. We provide details on the assessments for each study in the Characteristics of included studies table and summarise them in Figure 2, Figure 3 and in the text below.

Figure 2. Risk of bias graph: review authors' judgements about each risk of bias item presented as percentages across all included studies.

\section{Allocation sequence generation (selection bias)}

Allocation concealment (selection bias)

Baseline outcomes (selection bias)

Baseline characteristics (selection bias)

Incomplete outcome data (attrition bias)

Blinding (performance bias and detection bias)

Contamination (performance bias)

Selective reporting (reporting bias)

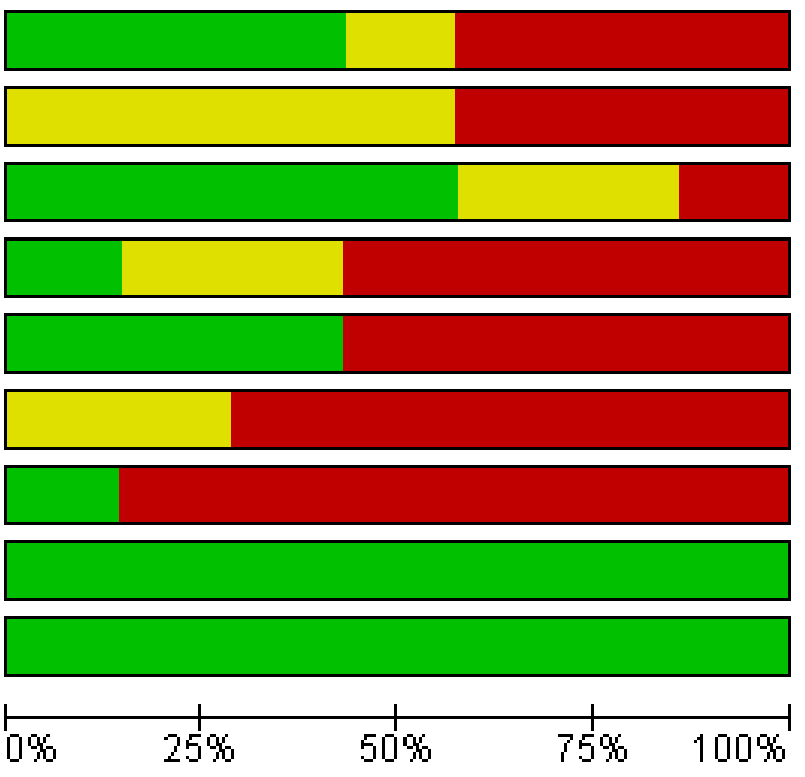

Other bias

$0 \%$

Low risk of bias

Unclear risk of bias

High risk of bias 
Figure 3. Risk of bias summary: review authors' judgements about each risk of bias item for each included study.

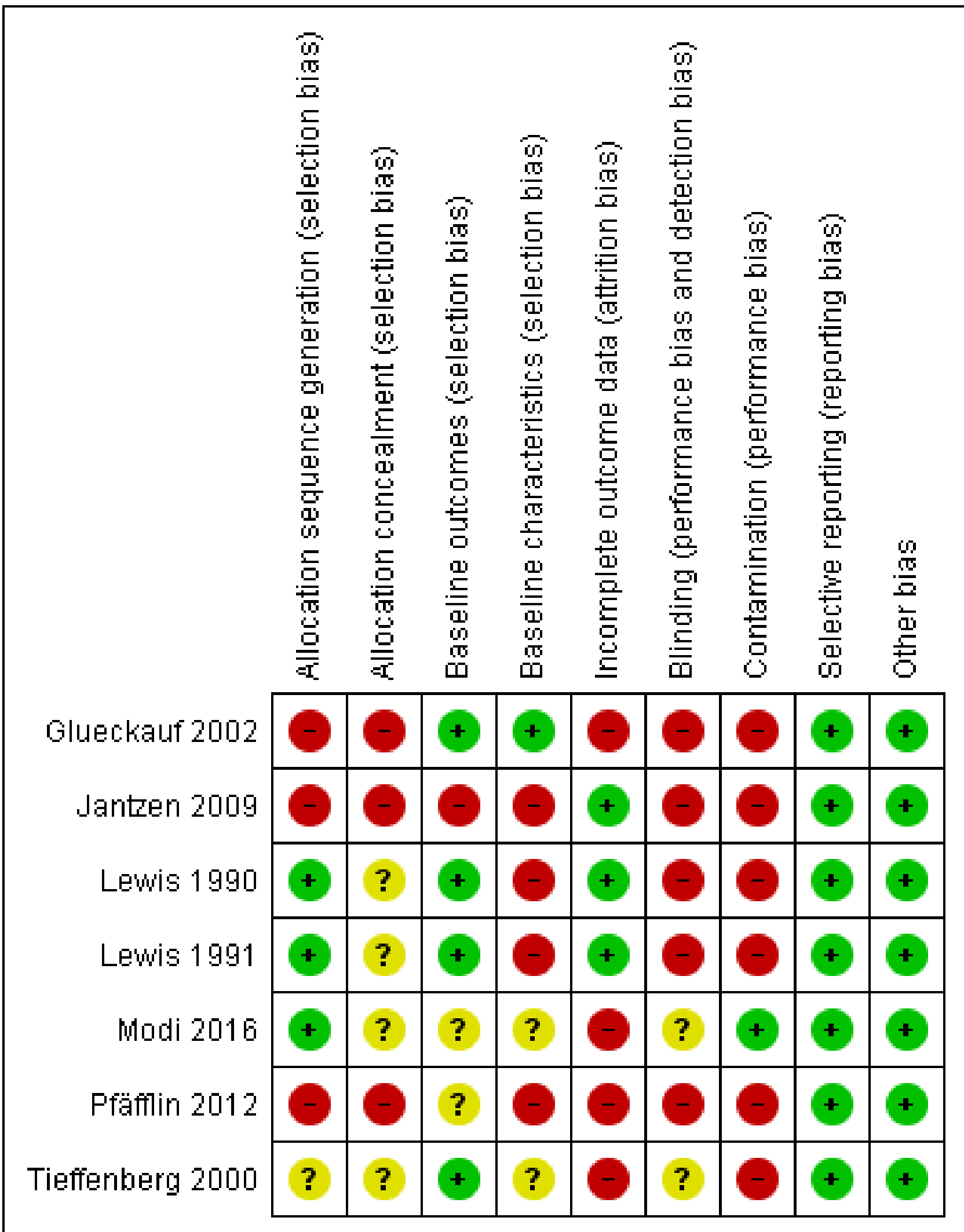




\section{Allocation}

\section{Allocation sequence generation}

For three interventions, the risk of bias was high: in two instances because participants were not randomised (Jantzen 2009; Pfäfflin 2012), and in a third because randomisation failed (Glueckauf 2002). The cluster-RCT evaluating ACINDES by Tieffenberg $2000 \mathrm{did}$ not report the details of randomisation (including the 'clustering techniques'), so we judged it to be at unclear risk of bias in this domain. The CEP studies (Lewis 1990; Lewis 1991), which employed a simple randomisation design for evaluating both parents and their children with epilepsy, were both at low risk of bias. Modi 2016 was also at low risk of bias, as it used block randomisation and stratified participants according to their treatment compliance in the preceding months (i.e. at preceding study visits 2, 3 or 4).

\section{Allocation concealment}

No RCT adequately reported on allocation concealment, so we assessed them to be at unclear risk of bias (Glueckauf 2002; Lewis 1990; Lewis 1991; Modi 2016; Tieffenberg 2000). The risk of bias was high in both of the controlled before-and-after studies (Jantzen 2009; Pfäfflin 2012).

\section{Baseline outcome measures}

One study was at high risk of bias for baseline outcome measures (Jantzen 2009). In the evaluation of FLIP\&FLAP, scores were notably higher at baseline for a number of quality of life outcomes in the control group (Jantzen 2009). Furthermore, the mean contact with healthcare providers in the past six months was 3.32 visits in the intervention group compared with 2.03 visits in the control group. Parents in the intervention group reported better social knowledge of epilepsy and more contacts with healthcare providers in the last six months. In Pfäfflin 2012, the risk of bias was unclear because a number of outcomes scores (including 'knowledge') were notably different between groups at baseline, all in favour of the control group; however, an analysis of covariance (ANCOVA) using 'knowledge at follow-up' as a dependent variable and 'knowledge at baseline' as a covariate confirmed a statistically significant group effect (control versus treatment) at follow-up after adjustment for baseline values. Modi 2016 took initial measurements in weeks 1 to 2 . The outcomes pertained to a small group, and it is not possible to draw conclusions about whether there any differences that may bias the results from the study. Hence the risk of bias in this study was unclear. In the other four studies, there were no imbalances in outcomes at baseline, so the risk of bias for these studies was low (Glueckauf 2002; Lewis 1990; Lewis 1991; Tieffenberg 2000).

\section{Baseline characteristics}

Four studies were at high risk of bias as a result of imbalances in baseline characteristics (Jantzen 2009; Lewis 1990; Lewis 1991; Pfäfflin 2012). The risk of bias was unclear in Tieffenberg 2000, which did not report baseline characteristics. The risk of bias was also unclear in Modi 2016 because there were apparent percentage differences between the control and treatment arms at baseline, but it was not clear whether these were statistically significant, and in any case the numbers of participants were small. Only Glueckauf 2002 was at low risk of bias due to there being no imbalances in baseline characteristics.

\section{Blinding}

No studies reported blinding for participants, clinicians or assessors. Because most outcomes for the interventions were derived from self-report, we considered that the lack of blinding introduced a high risk of bias in five studies (Glueckauf 2002; Jantzen 2009; Lewis 1990; Lewis 1991; Pfäfflin 2012). The evaluations of STAR and ACINDES were at unclear risk of bias because some of the outcomes reported were less susceptible to subjective interpretation (i.e. analysis of hospital and school records) (Modi 2016; Tieffenberg 2000).

\section{Contamination}

Six studies were at high risk of contamination because they assessed education-based programmes, and there was nothing to stop participants of intervention and control groups interacting with each other and sharing knowledge (Glueckauf 2002; Jantzen 2009; Lewis 1990; Lewis 1991;Pfäfflin 2012; Tieffenberg 2000). The fact that all studies failed to report blinding for participants, clinicians and assessors heightened the risk. In Modi 2016, the risk was low because it used a face-to-face evaluation with no obvious risk of contamination.

\section{Incomplete outcome data}

Loss to follow-up was relatively low in Jantzen 2009, Lewis 1990 and Lewis 1991 (less than 10\%). Hence, we judged these studies to be at low risk of bias. In the other studies, loss to follow-up was relatively high (over 10\%) in the intervention arm or in both arms (Glueckauf 2002; Modi 2016; Pfäfflin 2012; Tieffenberg 2000), meriting a judgement of high risk of bias.

\section{Selective reporting}

All studies reported findings for the outcomes described in the Methods sections (although Modi 2016 reported some outcomes in detail only in a supplementary appendix). Hence, all studies were at low risk of bias for selective reporting (Glueckauf 2002; Jantzen 2009; Lewis 1990; Lewis 1991; Modi 2016; Pfäfflin 2012; Tieffenberg 2000).

\section{Other potential sources of bias}

We did not identify any other potential sources of risk of bias in any of the included studies.

\section{Effects of interventions}

The types of outcomes reported varied considerably between studies, even within apparently similar types of outcomes. We therefore concluded that meta-analysis of the results would be inappropriate and have presented the results of the studies narratively. We only present the findings that we consider match the pre-defined outcomes of our review.

\section{Seizure frequency and severity}

Only two studies reported outcomes relating to seizure frequency and severity (Pfäfflin 2012; Tieffenberg 2000). The findings from the studies are summarised in Table 1 . The RCT evaluating ACINDES found a statistically significant difference in the number of epileptic seizures between groups over time (intervention: mean 0.80 seizures (standard deviation (SD) 1.46) at baseline versus 0.34 seizures (SD 0.98) at 12 months; control: 0.49 seizures (SD 1.15) at baseline versus 1.11 seizures (SD 2.77) at 12 months; 
$P=0.026$; (Tieffenberg 2000). The controlled before-and-after study by Pfäfflin 2012 reported that seizure frequency decreased significantly over time for children whose parents participated in FAMOSES $(P=0.037)$ but not in children of the parents of the control group $(P=0.156)$. The rate did not significantly differ between groups at three months (30.8\% with FAMOSES versus $20.0 \%$ with control; $P=0.397)$.

\section{Appropriateness and volume of medication prescribed}

As summarised in Table 2, three studies reported outcomes relating to the appropriateness and volume of medication prescribed (Jantzen 2009; Modi 2016; Pfäfflin 2012). Only in the controlled before-and-after study of FLIP\&FLAP were there statistically significant differences between groups at six months in terms of child's self-management skills (i.e. taking medication), as reported by the parents of the children $(P<0.001)$ (Jantzen 2009). For participants in the RCT evaluating STAR, there were no differences between the groups at three months in terms of antiepileptic drug adherence, although there were temporary improvements in the treatment period (Modi 2016). For participants in the controlled before-and-after study of FAMOSES, the tolerability and efficacy of antiepileptic drugs did not change significantly over time in either group (Pfäfflin 2012).

\section{Knowledge of information and advice received from professionals}

All studies except the evaluation by Glueckauf 2002 reported outcomes relating to knowledge of information and advice received from professionals. All studies reported statistically significant improvements for the intervention groups but three of these studies asked a wide range of questions about knowledge of information and advice (Jantzen 2009; Lewis 1990; Lewis 1991). Statistically significant results were reported for most, but not all items in the controlled before-and-after study of FLIP\&FLAP (Jantzen 2009). However, the results were more mixed in the RCTs evaluating CEP, from both the perspective of children (Lewis 1990) and adults (Lewis 1991). The other three studies all each included one (Pfäfflin 2012) or two items (Modi 2016; Tieffenberg 2000) relating to knowledge of information and advice received from professionals. Significant improvements for the intervention group compared with the controlled group were reported for all items in these three studies.The results from all of the studies are summarised in Table 3 and described in some detail below.

The cluster-RCT evaluating ACINDES reported that parents' knowledge improved in the intervention group at 12 months (from $22 \%$ to $56 \%$ ) compared to control (from $8 \%$ to $15 \%$, probability of gain $=0.62$, variance $=0.0026$ ), and fears and anxieties improved in the intervention group at 12 months (from 69\% to 30\% for fear of child's death) compared to no change in the control group (from $74 \%$ to $65 \%$, probability of gain $=0.63$, variance $=$ 0.0026) (Tieffenberg 2000). Similar results also occurred for children with statistically significant improvements in the intervention group compared to controls in knowledge, beliefs, attitudes and behaviours (probability of gain $=0.69$, variance $=0.007$ ).

At five months, the RCT evaluating CEP showed children in the intervention group were more likely to report generic gain in knowledge to the question, "What were the important things that you learned?" (mean: 64\% with intervention versus 47\% with control; $\mathrm{P}<0.01$ ) (Lewis 1990). Intervention parents were also more likely to report generic gain in knowledge to the question, "What were the important things that you learned?" (mean: 59\% with intervention versus $48 \%$ with control; $P<0.05$ ) (Lewis 1991).

Lewis 1990 reported that CEP resulted in statistically significant differences between groups in the percentage of children responding correctly to the following five knowledge items.

- Inappropriate to have objects in mouth during seizure (mean baseline to five months: $40.7 \%$ to $71.5 \%$ with intervention versus $44.3 \%$ to $52.2 \%$ with control; $P=0.002$ ).

- Inappropriate to restrain during seizure (mean baseline to five months: $34.9 \%$ to $79.7 \%$ with intervention versus $33.6 \%$ to $46.0 \%$ with control; $P=0.001$ ).

- Not required to visit emergency department after seizure (mean baseline to five months: $30.9 \%$ to $78.1 \%$ with intervention versus $29.2 \%$ to $52.2 \%$ with control; $P=0.001$ ).

- Purpose of electroencephalogram (EEG) (mean baseline to five months: $62.6 \%$ to $82.1 \%$ with intervention versus $63.7 \%$ to $69.0 \%$ with control; $\mathrm{P}=0.02$ ).

- Restriction of activities should be minimal (mean baseline to five months: $58.5 \%$ to $86.2 \%$ with intervention versus $58.4 \%$ to $68.1 \%$ with control; $P=0.001$ ).

Each group also reported slightly improved scores for the following five knowledge items (although all were reported to be 'not significant' between groups).

- Importance of taking medicines exactly as prescribed.

- Knowledge that seizures start in the brain.

- Purpose of drug blood levels to monitor dosage.

- Positive effects of participation in sports.

- Loss of sleep can trigger seizures.

In relation to specific items for parents, Lewis 1991 reported that CEP showed statistically significant differences between groups in the percentage of parents responding correctly to the following three knowledge items.

- Loss of sleep can trigger seizures (mean baseline to five months: $62.7 \%$ to $50.3 \%$ with intervention versus $66.3 \%$ to $65.2 \%$ with control; $P=0.005)$.

- Purpose of EEG (mean baseline to five months: $80.0 \%$ to $90.3 \%$ with intervention versus $81.1 \%$ to $83.3 \%$ with control; $P=0.05$ ).

- Purpose of drug blood levels to monitor dosage (mean baseline to five months: $63.4 \%$ to $7,9.6 \%$ with intervention versus $67.2 \%$ to $87.8 \%$ with control; $\mathrm{P}=0.04$ ).

Parents who undertook CEP were also more likely to recognise the importance of medicines (mean: $19 \%$ with intervention versus $9 \%$ with control; $P<0.01$ ). However, there were no statistically significant changes for the following seven knowledge items.

- Importance of taking medicines exactly as prescribed (mean baseline to five months: $94.6 \%$ to $97.3 \%$ with intervention versus $97.8 \%$ to $99.0 \%$ with control).

- Inappropriate to have objects in mouth during seizure (mean baseline to five months: $35.3 \%$ to $78.8 \%$ with intervention versus $35.6 \%$ to $76.1 \%$ with control).

- Inappropriate to restrain during seizure (mean baseline to five months: $52.2 \%$ to $76.3 \%$ with intervention versus $56.7 \%$ to $81.1 \%$ with control). 
- Not required to visit emergency department after seizure (mean baseline to five months: $68.1 \%$ to $93.0 \%$ with intervention versus $71.1 \%$ to $88.3 \%$ with control).

- Knowledge that seizures start in the brain (mean baseline to five months: $86.0 \%$ to $93.5 \%$ with intervention versus $86.7 \%$ to $90.0 \%$ with control.

- Restriction of activities should be minimal (mean baseline to five months: $88.6 \%$ to $96.7 \%$ with intervention versus $93.3 \%$ to $97.2 \%$ with control.

- Positive effects of participation in sports (mean baseline to five months: $80.5 \%$ to $95.1 \%$ with intervention versus $73.3 \%$ to $90.0 \%$ with control).

At three months, one controlled before-and-after study of FAMOSES showed statistically significant differences between groups in increased knowledge amongst parents ( $P<0.001)$ (Pfäfflin 2012; ). In addition, Pfäfflin 2012 followed up parents who participated in FAMOSES at five years and found that acquisition of new knowledge improved significantly over time $(P<0.001)$.

Also at three months, the RCT evaluating STAR reported that parents' knowledge improved in the intervention group on the two scores used $(P<0.05)$ (Modi 2016).

One controlled before-and-after study of FLIP\&FLAP showed statistically significant differences between groups over time (six months) in knowledge of epilepsy amongst children $(P<0.001)$ (Jantzen 2009). Knowledge amongst adolescents and parents was reported in relation to medical aspects, social aspects and seizure triggers. There was an improvement over time (six months) between groups in adolescents' knowledge for medical aspects ( $P$ $<0.001)$ and seizure triggers $(P<0.05)$. There were also statistically significant improvements between groups for parents' knowledge of medical aspects $(P<0.05)$ and seizure triggers $(P<0.001)$. Statistically significant improvements between groups were also reported for parents' knowledge of social aspects $(P<0.001)$ but not between groups of adolescents. A statistically significant improvement over time (six months) was also reported for parents in the intervention group in the ability to explain epilepsy to others $(P<0.001)$, but there was no statistically significant difference between groups over time for children or adolescents.

\section{Health and quality of life}

Five studies reported outcomes relating to health and quality of life (Glueckauf 2002; Lewis 1990; Lewis 1991; Pfäfflin 2012; Tieffenberg 2000). In addition, the RCT evaluating STAR asked parents of children who completed the intervention whether they thought the intervention improved their child's quality of life, but investigators did not ask this of parents of children in the control group, so between-arm comparisons were not possible (Modi 2016).The findings from the studies are summarised in Table 4 and generally show that for some items, interventions resulted in health and quality of life but for a greater number of items, they did not. These findings are described in a little more detail below.

Although a key goal of ACINDES is to improve social functioning and quality of life, the measures reported were more directly related to objective measures of social functioning (Tieffenberg 2000). These results are presented later. It was however reported that after participating in the groups, the parents of children with epilepsy allowed them to sleep at friends' homes more often (probability of gain $=0.59$, variance $=0.0026$ ) .
Lewis 1990, using Harter's Self-competency Scale, reported that at five months, CEP resulted in statistically significant differences between groups in social competency after scores were adjusted for pre-test values, age and sex $(P<0.05)$. There were no statistically significant changes (excluding children under eight years of age) for the following.

- Scholastic competency.

- Athletic competency.

- Appearance competency.

- Behaviour competency.

- Self-esteem competency.

In addition, Lewis 1990 reported that at five months, children in the intervention group were more likely to report gain in social skills (mean: $9 \%$ with intervention versus $2 \%$ with control; $P<0.02$ ) and participation in normal activities (mean: $11 \%$ with intervention versus $3.5 \%$ with control; $\mathrm{P}<0.03$ ). There were 'non-significant' changes for children's self-care skills, children's reports of parents' behaviours, and their disclosure of epileptic status. Interestingly, two-thirds of children reported doing nothing different as a result of programme participation.

For parents who participated in the CEP, Lewis 1991 reported that there were statistically significant differences between groups in parental anxiety as measured by Taylor Manifest Anxiety Scale. Parents in the intervention group showed greater reductions in anxiety than parents in the control group $(P<0.01)$. However, the effect was not statistically significant for fathers of children when analysed alone. At five months, there was a statistically significant difference in the proportion of parents who reported feeling less anxious and fearful after the sessions (mean: $31 \%$ with intervention versus $10 \%$ with control; $\mathrm{P}<0.001$ ). There were no differences in anxiety scores between people who attended all sessions and people who only attended some sessions.

In a controlled before-and-after study, at three months, there were no statistically significant differences over time between participants in the FAMOSES group and the control group in quality of life as assessed by parents or children (Pfäfflin 2012; findings reported by Rau 2006). However, the same study reported reduced social limitations over time amongst children in the intervention group compared to the control group $(P=0.017)$. Pfäfflin 2012 reported improvements over time for parents in the intervention group compared to the control group, namely: improved adaption to epilepsy amongst parents $(P=0.001)$; reduced anxiety about epilepsy amongst parents $(P=0.014)$; and improved parental ability to exert rules and limitations for children about the need for supervision $(P=0.031)$. There were no statistically significant differences between groups over time for a range of other outcomes that could be considered to report quality of life. These included coping with epilepsy (children and parents), anxiety about epilepsy (children), social limitations (children), sporting limitations (parents and children), rules and limitations for children about the need for supervision. There were no statistically significant differences between groups over time in attitudes towards epilepsy amongst children (reported by Rau 2006) or the impact of epilepsy as perceived by parents.

Glueckauf 2002, an RCT (but with failed randomisation) assessed counselling interventions using two types of outcome measures: first, self-perception of severity, frequency and improvement 
of family problems; and second, the improvement with those family problems identified using standardised scales of teenager functioning (pro-social and problem behaviour) in classroom and home settings. At one week post-treatment and six months followup, there were no statistically significant differences over time in outcome measures between groups for family issue frequency or severity for teenagers or parents. Scores measuring teenager functioning on the pro-social behaviour and problem behaviour scales were, however, significantly improved at both one week post-treatment and at six months follow-up for both parents and teachers $(P<0.01$ for all analyses).

The controlled before-and-after study of FLIP\&FLAP measured quality of life using the DISABKIDS modular health-related quality of life questionnaire (Jantzen 2009). Between groups, there was improved health-related quality of life in the social exclusion dimension amongst children and adolescents $(P<0.05)$ but not in parents. There were no statistically significant differences between groups of children, adolescents or parents for the other dimensions of the questionnaire: independence, emotion, physical limitation, social inclusion, medication and epilepsy impact social aspects of epilepsy.

\section{Objective measures of general health status}

No studies reported objective measures of general health status.

\section{Objective measures of social or psychological functioning}

Objective measures of social or psychological functioning were reported in four of the studies (Glueckauf 2002; Modi 2016; Pfäfflin 2012; Tieffenberg 2000). The findings are summarised in Table 5 and show variable results. At 12 months in one cluster-RCT (Tieffenberg 2000), there were significantly fewer emergency visits over time in children who received the ACINDES programme compared to control (mean at baseline to 12 months: 0.90 visits (SD 0.95) to 0.22 visits (SD 0.58) with intervention versus 0.83 visits (SD 0.95) to 0.46 visits (SD 0.66) with control; $P=0.046$ ) (Tieffenberg 2000). The number of regular medical visits also decreased over time in each group, but the differences were reported as 'not significant' (mean at baseline to 12 months: 3.64 visits (SD 3.01) to 3.06 visits (SD 2.57) with intervention versus 3.89 visits (SD 4.47) to 2.91 visits (SD 3.19) with control). The evaluation of ACINDES also showed statistically significant improvement in school absenteeism (mean number of absences per 100 school days at baseline to 12 months: 10.31 to 6.85 absences with intervention versus 9.32 to 9.21 absences with control; $P=0.011$ ). The controlled before-and-after study of FAMOSES reported that there was no difference in the number of days missed at school between participants in FAMOSES and the control group (Pfäfflin 2012, results reported in Rau 2006). At three months, the RCT evaluating STAR reported that parents' self-management improved in the intervention group $(P<0.05)$, but social problem-solving and parents' response to child illness did not (Modi 2016). Glueckauf 2002 measured adherence to the treatment programme (number of missed appointments and the extent of the homework completion) between the three different treatment modalities evaluated. There were no statistically significant differences at six months. However, randomisation failed for this study, so readers should interpret the results with caution. No other study considered the costs of care or treatment. No other studies reported on objective measures of social or psychological functioning.

\section{Costs of care or treatment}

No studies reported on the costs of care or treatment.

\section{DISCUSSION}

\section{Summary of main results}

This review included seven different studies of six interventions: five studies were designed as RCTs (Glueckauf 2002; Lewis 1990; Lewis 1991; Modi 2016; Tieffenberg 2000), and two were controlled before-and-after studies (Jantzen 2009; Pfäfflin 2012). We identified two types of intervention, both of which aimed to improve selfmanagement: educational interventions (Jantzen 2009; Lewis 1990 and Lewis 1991; Modi 2016; Pfäfflin 2012; Tieffenberg 2000) and a counselling intervention (Glueckauf 2002). The studies took place in diverse locations and investigated the use of a range of innovative interventions with children, adolescents and parents. Each study used a unique combination of outcome measures, mostly subjective in nature. No single intervention was consistently effective across the full range of reported outcomes.

\section{Overall completeness and applicability of evidence}

One cluster RCT, Tieffenberg 2000, and one controlled before-andafter study, Pfäfflin 2012, measured the impact of educational programmes (ACINDES and FAMOSES) on seizure frequency. These interventions suggest that educational interventions may result in seizure frequency decreasing over time in children. One randomised controlled trial, Modi 2016, and two controlled beforeand-after studies, Pfäfflin 2012 and Jantzen 2009, considered the impact of an educational programme on the tolerability and efficacy of antiepileptic medication. Only one study reported any impact (Jantzen 2009). No study reported objective measures of general health status or evaluated the costs of care or treatment.

Most outcomes measured in the studies were self-reported, considering knowledge about epilepsy or related issues. In general, the educational interventions appeared to have a positive impact, but the differences in how outcomes were collected prevented comparison of effectiveness between the studies. Therefore, it is unclear which intervention, if any, may be considered the best at improving these outcomes.

The cluster RCT evaluating ACINDES had a 12-month follow-up (Tieffenberg 2000), while all the studies reported outcomes at between three and six months after the intervention had finished. Therefore, it was impossible to elucidate the impact of any of the interventions on the long-term self-management of epilepsy.

Finally, although all of the studies investigated self-management improvement strategies, no individual strategy has been investigated with different study samples. Therefore, the generalisability of any of the interventions is unclear.

\section{Quality of the evidence}

The quality of evidence was generally poor, with all reports containing major methodological problems.

\section{Potential biases in the review process}

We did not identify any biases in the review process. 


\section{Agreements and disagreements with other studies or reviews}

The current review is an update of Lindsay 2010, a review we originally published in 2010 and updated in 2015 (Fleeman 2015). Despite identifying two additional controlled before-and-after study reports in the 2015 update (Jantzen 2009; Pfäfflin 2012), plus an additional RCT in the most recent update (Modi 2016), the overall findings remain unchanged. This is unsurprising given that one of the additional publications reported on an intervention (FLIP\&FLAP) previously evaluated (Pfäfflin 2012), published in German (Rau 2006), and included in our previous review. We are not aware of any other reviews that have considered care delivery and self-management strategies specifically for children or adolescents. However, three similar reviews have examined psychosocial treatment programmes in epilepsy (Mittan 2009), evidence-based models of care for people with epilepsy (Fitzsimons 2012), and care delivery and self-management strategies for adults with epilepsy (Bradley 2009; Bradley 2016). The review of care delivery and selfmanagement strategies for adults (Bradley 2009; Bradley 2016), which is currently being updated alongside this update for children, reported that two intervention types, specialist epilepsy nurse and self-management education, had some evidence of benefit. However, there was no clear evidence that other service models substantially improved outcomes for adults with epilepsy. The two other reviews reported similar findings (Fitzsimons 2012; Mittan 2009). Mittan 2009 suggested that the psychoeducational model, in particular the SEE programme (Helgeson 1990), may be the most promising in terms of delivering knowledge and psychosocial treatment outcomes, as well as being potentially the most costeffective. We note, though, that the review author of Mittan 2009 also developed the SEE programme in the 1980s and is one of the co-authors of Helgeson 1990. However, in a conflict of interest statement at the end of his review he stated that he "had no role in SEE program outcome research cited herein aside from presenting the program for independent researchers." All reviews have noted that there is currently a lack of evidence for the cost-effectiveness of any intervention.

A limitation of the current review is that all studies have methodological flaws, no intervention has been evaluated with different study samples and no interventions were sufficiently homogeneous enough to be included in a meta-analysis, so it is difficult to generalise the results and advise on practice. In addition, the descriptions of some interventions lack sufficient detail to allow their reproduction. In this respect, it might have been helpful to have included a process evaluation, so that the results were more generalisable.

\section{AUTHORS' CONCLUSIONS}

\section{Implications for practice}

The evidence from this review suggests that innovative models of service delivery may improve some outcomes relating to epilepsy in children and their parents. However, no single strategy improved a comprehensive range of user outcomes, and methodological deficiencies within each study mean that the results must be treated with caution.
Programme evaluations have not been replicated using different study samples, and in most cases the same team of researchers undertook the design, delivery and evaluation of each programme. At present there is insufficient evidence in favour of any single programme and so, while no programme showed negative impacts on children with epilepsy or their parents, it is not possible to recommend any single programme as being more effective than any other. No programme showed consistent improvement across all of the assessed outcomes. Healthcare professionals and families need to be aware of this when considering any of these strategies for implementation.

\section{Implications for research}

We identified six distinct self-management programmes for educating or counselling children with epilepsy and their parents. However, no intervention has been evaluated with different study samples and the studies show methodological flaws, were not independently assessed and had inconsistent results. The evidence from this review suggests that innovative models of service delivery may improve some outcomes relating to epilepsy in children and to the impact that epilepsy can have on parents. However, no single strategy improved a comprehensive range of user outcomes, and methodological deficiencies within each study mean that readers should interpret the results with caution.

As a result, further studies are needed that:

- offer an improved quality of study design and reporting;

- improve generalisability (e.g. include a full description of the intervention, a process evaluation, and a multicentred assessment of the benefits for more than one population and service provider);

- evaluate the effects of interventions for those subgroups most likely to benefit (e.g. children with newly diagnosed epilepsy, children with learning disabilities);

- consider objective outcomes and the cost-effectiveness of service models shown to be beneficial.

To maximise the potential of future studies for generalisability and to ensure study quality, we would recommend randomised controlled trials rather than observational studies. Studies should also ensure that the interventions are adequately defined and described and that investigators take into account contextual factors in the study design. Where socially complex interventions such as these are under study, enough service providers must be included to ensure that individual characteristics do not bias the results.

\section{ACKNOWLEDGEMENTS}

We would like to thank Laura Burfoot, who helped us to summarise the results from the studies in the original review. We would also like to thank all the information specialists who conducted the searches for the original and updated review.

We would like to acknowledge Bruce Lindsay for his valuable contribution to the original protocol and previous versions of this review. 


\section{R E F E R E N C E S}

\section{References to studies included in this review}

\section{Glueckauf 2002 \{published data only\}}

Glueckauf RL, Fritz SP, Ecklund-Johnson EP, Liss HJ, Dages P, Carney P. Videoconferencing-based family counseling for rural teenagers with epilepsy: phase 1 findings. Rehabilitation Psychology 2002;47(1):49-72.

\section{Jantzen 2009 \{published data only\}}

Jantzen S, Müller-Godeffroy E, Hallfahrt-Krisl T, Aksu F, Püst B, Kohl B, et al. FLIP\&FLAP-a training programme for children and adolescents with epilepsy, and their parents. Seizure 2009; Vol. 18 , issue $7: 478-86$

\section{Lewis 1990 \{published data only\}}

Lewis MA, Salas I, de la Sota A, Chiofalo N, Leake B. Randomized trial of a program to enhance the competencies of children with epilepsy. Epilepsia 1990;31(1):101-9.

\section{Lewis 1991 \{published data only\}}

Lewis MA, Hatton CL, Salas I, Leake B, Chiofalo N. Impact of the Children's Epilepsy Program on parents. Epilepsia 1991;32(3):365-75.

\section{Modi 2016 \{published data only\}}

Modi Avani C, Guilfoyle Shanna M, Mann Krista A, Rausch Joseph R. A pilot randomized controlled clinical trial to improve antiepileptic drug adherence in young children with epilepsy. Epilepsia 2016;57(3):e69-75.

\section{Pfäfflin 2012 \{published data only\}}

* Pfäfflin M, Petermann F, Rau J, May TW. The psychoeducational program for children with epilepsy and their parents (FAMOSES): results of a controlled pilot study and a survey of parent satisfaction over a five-year period. Epilepsy \& Behavior 2012;25(1):11-6.

Rau J, May TW, Pfäfflin M, Heubrock D, Petermann F. Education of children with epilepsy and their parents by the ModularEducation Program Epilepsy for Families (FAMOSES) - results of an evaluation study [Schulung von Kinderen mit Epilepsieund deren Eltern mit dem Modularen Schulungsprogramm Epilepsie für Familien (FAMOSES) - Ergebnisse einerEvaluationsstudie]. Rehabilitation 2006;45:27-39. []

\section{Tieffenberg 2000 \{published data only\}}

Tieffenberg JA, Wood El, Alonso A, Tossutti MS, Vicente MF. A randomized field trial of ACINDES: a child-centered training model for children with chronic illnesses (asthma and epilepsy). Journal of Urban Health: Bulletin of the New York Academy of Medicine 2000;77(2):280-97.

\section{References to studies excluded from this review}

\section{Austin 2002 \{published data only\}}

Austin JK, McNelis AM, Shore CP, Dunn DW, Musick B. A feasibility study of a family seizure management program:
"Be Seizure Smart". Journal of Neuroscience Nursing 2002;34(1):30-7.

Hallfahrt 2007 \{published data only\}

Hallfahrt T. FLIP\&FLAP educational program in epilepsy in childhood and adolescence. Kinderkrankenschwester 2007;26(12):516-21.

\section{Ibinda 2014 \{published data only\}}

Ibinda Fredrick, Mbuba Caroline K, Kariuki Symon M, Chengo Eddie, Ngugi Anthony K, Odhiambo Rachael, et al. Evaluation of Kilifi epilepsy education programme: a randomized controlled trial. Epilepsia 2014;55(2):344-52.

\section{Li 2013 \{published data only\}}

Li J, Si Y, Hu J, Liu L, Deng Y, He J, et al. Enhancing medical compliance of patients with convulsive epilepsy in rural community: a randomized intervention trial. Epilepsia 2013;54(11):1988-96.

\section{Mar 2005 \{published data only\}}

Mar S, Dunkley C, Al-Ansari I, Whitehouse WP. Comparison of a dedicated children's seizure clinic to mixed general paediatric clinics. Child: Care, Health and Development 2005;31(5):597-602.

Modi 2013 \{published data only\}

Modi Avani C, Guilfoyle Shanna M, Rausch Joseph. Preliminary feasibility, acceptability, and efficacy of an innovative adherence intervention for children with newly diagnosed epilepsy. Journal of Pediatric Psychology 2013;38(6):605-16.

Price 2004 \{published data only\}

Price V, Murphy SO, Cureton VY. Increasing self-efficacy and knowledge through a seizure education programme for specia education teachers. Journal of School Nursing 2004;20(1):43-9.

Shore 2008 \{published data only\}

Shore CP, Perkins SM, Austin JK. The Seizures and Epilepsy Education (SEE) program for families of children with epilepsy: a preliminary study. Epilepsy \& Behavior 2008; Vol. 12, issue 1:157-64.

\section{Snead 2004 \{published data only\}}

Snead K, Ackerson J, Bailey K, Schmitt MM, Madan-Swain A, Martin RC. Taking charge of epilepsy: the development of a structured psychoeducational group intervention for adolescents with epilepsy and their parents. Epilepsy and Behavior 2004;5(4):547-56.

\section{References to studies awaiting assessment \\ NCT02349529 \{published data only\}}

NCT02349529. An exploratory RCT of a psychosocial group intervention for epilepsy [An exploratory randomised controlled trial of a manualised psychosocial group intervention for young people with epilepsy (PIE)]. clinicaltrials.gov/ct2/show/ NCT02349529 (first received 29 January 2015). 


\section{References to ongoing studies}

IRCT2015060122514N1 \{published data only\}

IRCT2015060122514N1. The effect of self-care education based on short message service in adolescents with epilepsy [Comparison of self-care education based on short message service and pamphlet on self-efficacy and adherence to the medication regimen in adolescents with epilepsy]. http:// en.irct.ir/trial/19406 Registration date: 27 October 2015.

\section{Additional references}

\section{Austin 1997}

Austin JK, Boer H. Disruption in social functioning and services facilitating adjustment for the child and adult with epilepsy. In: Engel J, Pedley T editor(s). Epilepsy: A Comprehensive Textbook. Philadelphia: Lippincott-Raven, 1997:191-201.

\section{Bandstra 2008}

Bandstra N, Camfield C, Camfield P. Stigma of epilepsy. Canadian Journal of Neurological Sciences 2008;35(4):436-40.

\section{Berg 2010}

Berg AT, Berkovic SF, Brodie MJ, Buchhalter J, Cross JH, van Emde Boas W, et al. Revised terminology and concepts for organization of seizures and epilepsies: report of the ILAE Commission on Classification and Terminology, 2005-2009. Epilepsia 2010;51(4):676-85.

\section{Betts 1992}

Betts T. Epilepsy services. What people need, what they want, what they get. Acta Neurologica Scandinavica 1992;140(2):95-100.

\section{Bradley 2009}

Bradley PM, Lindsay B. Care delivery and selfmanagement strategies for adults with epilepsy. Cochrane Database of Systematic Reviews 2009, Issue 4. [DOI: 10.1002/14651858.CD006244.pub2]

\section{Bradley 2016}

Bradley P M, Lindsay B, Fleeman N. Care delivery and self management strategies for adults with epilepsy. Cochrane Database Syst Rev 2016;2:Cd006244.

\section{Bradley 2016a}

Bradley PM, Lindsay B, Fleeman N. Care delivery and self management strategies for adults with epilepsy. Cochrane Database of Systematic Reviews 2016, Issue 2. [DOI: 10.1002/14651858.CD006244.pub3]

\section{Chappell 1992}

Chappell B. Epilepsy: patient views on their condition and treatment. Seizure 1992;1(2):103-9.

\section{Clark 2008}

Clark NM, Cabana MD, Nan B, Gong ZM, Slish KK, Birk NA, et al. The clinician-patient partnership paradigm: outcomes associated with physician communication behavior. Clinical Pediatrics 2008;47(1):49-57.

\section{Clark 2010}

Clark NM, Stoll S, Youatt EJ, Sweetman M, Derry R, Gorelick A. Fostering epilepsy self management: the perspectives of professionals. Epilepsy \& Behavior 2010;19(3):255-63.

\section{Cochrane EPOC 2012}

Cochrane Effective Practice and Organisation of Care Review Group. Data Collection Checklist. Ottawa, ON: Ottawa Hospital Research Institute 2012

\section{Egger 1997}

Egger M, Davey Smith G, Schneider M, Minder C. Bias in meta-analysis detected by a simple,graphical test. $B M J$ 1997;315:629-34.

\section{Elwyn 2003}

Elwyn G, Todd S, Hibbs R, Thapar A, Edwards P, Webb A, et al. A 'real puzzle': the views of patients with epilepsy about the organisation of care. BMC Family Practice 2003;4:4.

\section{England 2012}

England MJ, Liverman CT, Schultz AM, Strawbridge LM. Epilepsy across the spectrum: promoting health and understanding. A summary of the Institute of Medicine report. Epilepsy \& Behavior 2012;25(2):266-76

\section{FAMOSES Project Group 2007}

Wohlraba GC, Rinnert S, Bettendorf U, Fischbach H, Heinen G, Klein P, et al. FAMOSES Project Group. FAMOSES: a modular educational program for children with epilepsy and their parents. Epilepsy \& Behaviour 2007;10(1):44-8.

\section{Fitzsimons 2012}

Fitzsimons M, Normand C, Varley J, Delanty N. Evidence-based models of care for people with epilepsy. Epilepsy \& Behavior 2012;23(1):1-6.

\section{Helgeson 1990}

Helgeson DC, Mittan R, Tan S-R, Chayasirisobhon S. Sepulveda Epilepsy Education: the efficacy of a psychoeducational treatment programme in treating medical and psychosocial aspects of epilepsy. Epilepsia 1990;31(1):75-82.

\section{Higgins 2003}

Higgins JPT, Thompson SG, Deeks JJ, Altman DG. Measuring inconsistency in meta-analyses.. BMJ 2003;327:557-60.

\section{Higgins 2011}

Higgins JP, Green S (editors). Cochrane Handbook for Systematic Reviews of Interventions Version 5.1.0 (updated March 2011). The Cochrane Collaboration, 2011. Available from www.cochrane-handbook.org.

\section{Mittan 2009}

Mittan RJ. Psychosocial treatment programs in epilepsy: a review. Epilepsy \& Behavior 2009;16(3):371-80.

\section{Rau 2006}

Rau J, May M, Pfäfflin M, Heubrock D, Petermann F. Eudcation of children with epilepsy and their parents by the Modular 
Education Program Epilepsy for Families (FAMOSES) - results of an evaluation study. Rehabilitation 2006;45(1):27-39.

\section{Sander 1990}

Sander JW, Hart YM, Johnson AL, Shorvon SD. National General Practice Study of Epilepsy: newly diagnosed epileptic seizures in a general population. Lancet 1990;336(8726):1267-71.

\section{SIGN 2003}

Scottish Intercollegiate Guidelines Network (SIGN). Diagnosis and management of epilepsy in adults: A national clinical guideline (no. 70). Diagnosis and management of epilepsy in adults: A national clinical guideline (no. 70). Edinburgh: Scottish Intercollegiate Guidelines Network, Royal College of Physicians, 2003.

\section{SIGN 2005}

Scottish Intercollegiate Guidelines Network (SIGN). Diagnosis and management of epilepsies in children and young people: a national clinical guideline (no. 81). Edinburgh: Scottish Intercollegiate Guidelines Network, 2005.

\section{Thapar 1996}

Thapar AK. Care of patients with epilepsy in the community: will new initiatives address old problems?. British Journal of General Practice 1996;46(402):37-42.

\section{CHARACTERISTICS OF STUDIES}

Characteristics of included studies [ordered by study ID]

\section{WHO 2012}

World Health Organization. Fact sheet 999, epilepsy, 2012. www.who.int/mediacentre/factsheets/fs999/en/index.htm (accessed 16 December 2013).

\section{References to other published versions of this review}

\section{Fleeman 2015}

Fleeman N, Bradley PM, Lindsay B. Care delivery and self management strategies for children with epilepsy. Cochrane Database of Systematic Reviews 2015, Issue 12. [DOI: 10.1002/14651858.CD006245]

\section{Lindsay 2006}

Lindsay B, Bradley PM. Care delivery and self-management strategies for children with epilepsy. Cochrane Database of Systematic Reviews 2006, Issue 4. [DOI: 10.1002/14651858.CD006245]

\section{Lindsay 2010}

Lindsay B, Bradley P. Care delivery and self-management strategies for children with epilepsy. Cochrane Database of Systematic Reviews 2010, Issue 12. [DOI: 10.1002/14651858.CD006245.pub2]

* Indicates the major publication for the study

Glueckauf 2002

\begin{tabular}{ll}
\hline Methods & Study type: Randomised controlled trial, with three arms \\
& Duration of study: 6 months follow-up \\
\hline Participants & Population type: Teenagers (aged $12-19$ years) with epilepsy and behaviour problems ( $\mathrm{n}=22$ ) and their \\
parents ( $\mathrm{n}=36 ;$ fathers, $\mathrm{n}=15 ;$ mothers, $\mathrm{n}=21$ ) \\
Setting: Community (participants home or professional's office) in rural Mideast USA \\
Age, mean (SD), of teenagers, years: 15.4 (2.5) \\
Male teenagers: $14 / 22$ (63.6\%) \\
Health status: All 22 teenagers had epilepsy and behaviour problems. Most teenagers (19/22 [86.4\%] \\
had complex partial seizures (10/22 [45.5\%]), generalized seizures (tonic-clonic 5/22 [22.7\%] and ab- \\
sence episodes (1/22 [4.5\%]) or a combination of partial and generalized seizures (3/22 [13.6\%]) \\
Average monthly seizure frequency 6 months prior to assessment, mean (SD) $18.2(33.7)$ \\
Mean (SD) age of onset of seizures, years: 8.2 (4.9) \\
Age, mean (SD) of fathers: 43.5 (5.5) \\
Age, mean (SD) of mothers: $41.1(5.5)$ \\
Single parent households: $8 / 36$ (22.2\%) \\
Mean (SD) years of education of fathers: $13.5(1.6)$ \\
Mean (SD) years of education of mothers: 13.7 (2.4)
\end{tabular}

Interventions Experimental group 1: Issue Specific Family Counseling Model (ISFCM) delivered at home via video-con-
ferencing or speaker phone $(n=9)$
Experimental group 2: ISFCM delivered face-to-face in the counsellor's office $(n=6)$
Control: waiting-list control $(n=7)$ 
Glueckauf 2002 (Continued)

Outcomes

Severity and frequency of the behaviour problem (pre-test to 1-week post-treatment, pre-test to 6months post-treatment, teenagers versus parents and parents versus teachers); teenager's functional ability in school and home

Notes Published data, no unpublished data sought

\section{Risk of bias}

Bias Authors' judgement Support for judgement

Allocation sequence gen- High risk

eration (selection bias)

No details of how participants were allocated were provided, but the randomisation failed in this trial as several families allocated to video-conference-based family counselling (VFC) were unable to support it technically and were offered speakerphone family counselling as an alternative (SFC)

\begin{tabular}{ll}
\hline $\begin{array}{l}\text { Allocation concealment } \\
\text { (selection bias) }\end{array}$ & High risk \\
& $\begin{array}{l}\text { The randomisation failed in this trial as several families allocated to video-con- } \\
\text { ference-based family counselling (VFC) were unable to support it technically } \\
\text { and were offered speakerphone family counselling as an alternative (SFC) }\end{array}$
\end{tabular}

\begin{tabular}{l}
\hline $\begin{array}{l}\text { Baseline outcomes (selec- Low risk } \\
\text { tion bias) }\end{array}$ \\
\hline
\end{tabular}

\begin{tabular}{lll}
\hline $\begin{array}{l}\text { Baseline characteristics } \\
\text { (selection bias) }\end{array}$ & Low risk & No baseline differences between groups were reported \\
\hline $\begin{array}{l}\text { Incomplete outcome data } \\
\text { (attrition bias) }\end{array}$ & High risk & $\begin{array}{l}31 \% \text { of families did not attend any counselling, and a further 13\% did not com- } \\
\text { plete all sessions. Parents in the treatment dropout group reported a greater } \\
\text { mean frequency of pre-test family problems than parents who completed the } \\
\text { counselling programme }\end{array}$ \\
\hline
\end{tabular}

\begin{tabular}{lll}
\hline $\begin{array}{l}\text { Blinding (performance } \\
\text { bias and detection bias) } \\
\text { All outcomes }\end{array}$ & High risk & $\begin{array}{l}\text { None of the participants, clinicians or assessors appeared to have been blind- } \\
\text { ed. The subjective nature of the outcomes measured (all by self-reported } \\
\text { questionnaire) means this may have introduced bias }\end{array}$ \\
$\begin{array}{l}\text { Contamination (perfor- } \\
\text { mance bias) }\end{array}$ & High risk & $\begin{array}{l}\text { Randomisation was potentially done at the patient level, rather than by an in- } \\
\text { dependent centre, so there is nothing to stop people in intervention and con- } \\
\text { trol groups interacting with each other and sharing knowledge }\end{array}$ \\
\hline
\end{tabular}

Selective reporting (re- Low risk All outcomes detailed in the methods were reported in the results
porting bias)

Other bias Low risk No other potential sources of risk of bias identified

\begin{tabular}{|c|c|}
\hline Methods & $\begin{array}{l}\text { Study type: Multicentre non-randomised 2-group controlled before-and-after study } \\
\text { Duration of study: } 6 \text { months follow-up }\end{array}$ \\
\hline Participants & $\begin{array}{l}\text { Population type: Children (aged 8-11 years) }(n=54) \text { and adolescents (aged } 12-16 \text { years) with epilepsy ( } \mathrm{n} \\
=87) \text { and their parents }(n=156) \\
\text { Setting: } 10 \text { Epilepsy centres in Germany } \\
\text { Age, mean (SD) [range] of children and adolescents, years: Experimental } 11.6(3.0) \text { [6-17]; Control } 11.7 \\
(2.5) \text { [6-16] } \\
\text { Male children and adolescents: Experimental 35/75 (44.9\%); Control } 37 / 82(45.1 \%)\end{array}$ \\
\hline
\end{tabular}


Health status: Where determined, most children and adolescents had complex partial seizures (Experimental 15/54 [27.8\%]; Control 15/48 [31.3\%]), tonic-clonic seizures (Experimental 19/54 [35.2\%]; Control 22/48 [45.8\%]) or absence episodes (Experimental 13/54 [24.1\%]; Control 3/48 [6.3\%])

Mean (SD) duration of epilepsy, years: Experimental 4.7 (4.0); Control 5.6 (3.7)

Seizures within last 6 months: Experimental 36/78 (46.2\%); Control 25/73 (32.1\%)

Children and adolescents with comorbidities: Experimental 24/75 (32.0); Control 13/75 (17.3)

Parental education >Grade 10: Experimental 36/76 (47.4\%); Control 31/76 (40.8\%)

Fathers employed: Experimental 57/64 (89.1\%); Control 67/69 (97.1\%)

Mothers employed: Experimental 50/74 (67.6\%); Control 58/76 (76.3\%)

\begin{tabular}{ll}
\hline Interventions & $\begin{array}{l}\text { Experimental group: educational sessions using age-appropriate material based on an inventory used } \\
\text { in family and behaviour therapy }(\mathrm{n}=78) \\
\text { Control: waiting-list control }(\mathrm{n}=82)\end{array}$ \\
\hline Outcomes & $\begin{array}{l}\text { Seizure free episodes; knowledge of epilepsy; self-management skills; epilepsy-related worries; health- } \\
\text { related quality of life; communication skills; satisfaction with the intervention } \\
\text { All outcomes measured at baseline and 6-months follow-up }\end{array}$ \\
\hline Notes & Published data, no unpublished data sought
\end{tabular}

\section{Risk of bias}

\begin{tabular}{lll}
\hline Bias & Authors' judgement & Support for judgement \\
\hline $\begin{array}{l}\text { Allocation sequence gen- } \\
\text { eration (selection bias) }\end{array}$ & High risk & Controlled before-and-after study \\
\hline $\begin{array}{l}\text { Allocation concealment } \\
\text { (selection bias) }\end{array}$ & High risk & Controlled before-and-after study \\
\hline $\begin{array}{l}\text { Baseline outcomes (selec- } \\
\text { tion bias) }\end{array}$ & High risk & $\begin{array}{l}\text { For a number of quality of life outcomes, scores were notably higher in the } \\
\text { control group and the mean contact with healthcare providers in the past } 6 \\
\text { months was 3.32 in the intervention group compared with 2.03 in the control } \\
\text { group. More parents in the control group reported a longer seizure-free dura- } \\
\text { tion, more parents in the intervention group reported better social knowledge } \\
\text { of epilepsy and more contacts with healthcare providers in the last } 6 \text { months }\end{array}$ \\
\hline $\begin{array}{l}\text { Baseline characteristics } \\
\text { (selection bias) }\end{array}$ & High risk & $\begin{array}{l}\text { A number of baseline differences were apparent between the } 2 \text { groups that } \\
\text { were not adjusted for in analysis (however, for } 1 \text { of the variables, educational } \\
\text { status, and for } 1 \text { of the outcomes, epilepsy knowledge, a univariate analysis } \\
\text { of variance with repeated measurements was performed with epilepsy knowl- } \\
\text { edge as a dependent variable and time and educational status as independent } \\
\text { variables) }\end{array}$
\end{tabular}

\begin{tabular}{|c|c|c|}
\hline $\begin{array}{l}\text { Incomplete outcome data } \\
\text { (attrition bias) } \\
\text { All outcomes }\end{array}$ & Low risk & $\begin{array}{l}\text { It was reported that the loss to follow-up was less than } 10 \% \text { in all subgroups of } \\
\text { the sample }\end{array}$ \\
\hline $\begin{array}{l}\text { Blinding (performance } \\
\text { bias and detection bias) } \\
\text { All outcomes }\end{array}$ & High risk & $\begin{array}{l}\text { None of the participants, clinicians or assessors appeared to have been blind- } \\
\text { ed. The subjective nature of the outcomes measured (all by self reported ques- } \\
\text { tionnaire) means this may have introduced bias }\end{array}$ \\
\hline
\end{tabular}

\begin{tabular}{|c|c|c|}
\hline $\begin{array}{l}\text { Contamination (perfor- } \\
\text { mance bias) }\end{array}$ & High risk & $\begin{array}{l}\text { This was a waiting-list comparison and families were recruited from the same } \\
\text { centres over Germany, so those in the intervention and control groups would } \\
\text { theoretically have been able to share information }\end{array}$ \\
\hline
\end{tabular}

Selective reporting (re- Low risk All outcomes detailed in the methods were reported in the results
porting bias)


Jantzen 2009 (Continued)

Other bias Low risk No other potential sources of risk of bias identified

Lewis 1990

\begin{tabular}{|c|c|}
\hline Methods & $\begin{array}{l}\text { Study type: Randomised controlled trial } \\
\text { Duration of study: } 5 \text { months follow-up }\end{array}$ \\
\hline Participants & $\begin{array}{l}\text { Population type: Children (aged 7-14 years) with epilepsy }(\mathrm{n}=236) \\
\text { Setting: Clinic based educational programme in Santiago, Chile } \\
\text { Health status: Where information was available from school records, 'slightly more than half' of all chil- } \\
\text { dren had behavioural problems. Where determined, } 59 / 132(44.7 \%) \text { of children had generalized ton- } \\
\text { ic-clonic seizure disorders (Calculated from following: Medical records from physicians' providing care } \\
\text { could be obtained for only } 56 \% \text { of the children of whom } 45 \% \text { had generalized tonic-clonic seizure disor- } \\
\text { ders) } \\
\text { Age, mean (SD) of children, years: Experimental } 10.1(2.2) \text {; Control } 9.9(2.1) \\
\text { Male children: Experimental } 48.0 \% \text {; Control } 52.0 \%\end{array}$ \\
\hline
\end{tabular}

Interventions Experimental group: Children's Epilepsy Programme, a counselling model based on Rogerian principles (child-centred family-focused (active learning) programme) $(n=123)$

Control: traditional educational format (passive learning) consisting of $3 \times 2$-hour sessions conducted by a physician who gave traditional lectures followed by question and answer sessions to present the same information related to epilepsy that the experimental group received $(n=113)$

Outcomes Knowledge about seizures; self-perceived competency, knowledge, behaviour and parent's behaviour All outcomes measured at baseline and 5-months follow-up

Notes

Evaluation of same intervention as Lewis 1991 but focuses on the children's perspective

Published data, no unpublished data sought

\section{Risk of bias}

\begin{tabular}{lll}
\hline Bias & Authors' judgement & Support for judgement \\
\hline $\begin{array}{l}\text { Allocation sequence gen- } \\
\text { eration (selection bias) }\end{array}$ & Low risk & $\begin{array}{l}\text { From a master list of children aged 7-14 years, groups of 20 families were se- } \\
\text { lected and assigned numbers and randomly selected for the control and inter- } \\
\text { vention groups }\end{array}$ \\
\hline $\begin{array}{l}\text { Allocation concealment } \\
\text { (selection bias) }\end{array}$ & Unclear risk & Not described \\
\hline $\begin{array}{l}\text { Baseline outcomes (selec- } \\
\text { tion bias) }\end{array}$ & Low risk & Outcomes were not imbalanced at baseline \\
\hline $\begin{array}{l}\text { Baseline characteristics } \\
\text { (selection bias) }\end{array}$ & High risk & $\begin{array}{l}\text { Some baseline differences were apparent (ordinal position, grades in school, } \\
\text { living with both parents and number of siblings) }\end{array}$ \\
\hline $\begin{array}{l}\text { Incomplete outcome data } \\
\text { (attrition bias) } \\
\text { All outcomes }\end{array}$ & Low risk & $\begin{array}{l}\text { Only 78.6\% of children in the intervention group and 52\% of children in the } \\
\text { control group attended all the required sessions. However, pre- and post-test } \\
\text { data were available for almost 95\% of children. No intention-to-treat analy- } \\
\text { sis explicitly reported, but data were reported for each participant in the final } \\
\text { analysis for some, but not all, outcomes despite attendance at the educational } \\
\text { programme being incomplete. }\end{array}$ \\
\hline
\end{tabular}


Lewis 1990 (Continued)

\begin{tabular}{|c|c|c|}
\hline $\begin{array}{l}\text { Blinding (performance } \\
\text { bias and detection bias) } \\
\text { All outcomes }\end{array}$ & High risk & $\begin{array}{l}\text { Participants and clinicians were not blinded; it is unclear if the trained inter- } \\
\text { viewers were blinded. The subjective nature of the outcomes measured (by } \\
\text { self-reported questionnaire) means this may have introduced bias. }\end{array}$ \\
\hline
\end{tabular}

\begin{tabular}{lll}
\hline $\begin{array}{l}\text { Contamination (perfor- } \\
\text { mance bias) }\end{array}$ & High risk & $\begin{array}{l}\text { There was nothing to prevent participants in the intervention and control } \\
\text { groups interacting with each other and sharing knowledge. }\end{array}$ \\
\hline $\begin{array}{l}\text { Selective reporting (re- } \\
\text { porting bias) }\end{array}$ & Low risk & All outcomes detailed in the methods were reported in the results. \\
\hline Other bias & Low risk & No other potential sources of risk of bias identified \\
\hline
\end{tabular}

Lewis 1991

\begin{tabular}{ll}
\hline Methods & $\begin{array}{l}\text { Study type: Randomised controlled trial } \\
\text { Duration of study: } 5 \text { months follow-up }\end{array}$ \\
\hline Participants & Population type: Parents of children with epilepsy aged $7-14$ years ( $\mathrm{n}=365 ;$ fathers, $\mathrm{n}=136 ;$ mothers, $\mathrm{n}$ \\
& 229) \\
& Setting: Clinic based educational programme in Santiago, Chile \\
& Health status: Where determined, $59 / 132(44.7 \%)$ of children had generalized tonic-clonic seizure dis- \\
& orders (Calculated from following: Medical records from physicians' providing care could be obtained \\
& for only $56 \%$ of the children of whom $45 \%$ had generalized tonic-clonic seizure disorders) \\
& Single parent households: Experimental $26.2 \%$; Control $19.0 \%$ \\
& Fathers employed: Experimental $91.0 \%$; Control $96.0 \%$ \\
& Mothers employed: Experimental $26.0 \% ;$ Control $31.0 \%$
\end{tabular}

Interventions Experimental group: Children's Epilepsy Programme, a counselling model based on Rogerian principles (child-centred family-focused active learning program) $(n=185)$

Control: traditional educational format (passive learning) consisting of $3 \times 2$-hour sessions conducted by a physician who gave traditional lectures followed by question and answer sessions to present the same information related to epilepsy that the experimental group received $(n=180)$

\begin{tabular}{|c|c|c|}
\hline Outcomes & \multicolumn{2}{|c|}{$\begin{array}{l}\text { Parental knowledge and anxiety; perceptions of the programme's efficacy including parental reactions } \\
\text { to child's seizures } \\
\text { All outcomes measured at baseline and } 6 \text {-months follow-up }\end{array}$} \\
\hline Notes & \multicolumn{2}{|c|}{$\begin{array}{l}\text { Evaluation of same intervention as Lewis } 1990 \text { but focuses on the parents' perspective } \\
\text { Published data, no unpublished data sought }\end{array}$} \\
\hline \multicolumn{3}{|l|}{ Risk of bias } \\
\hline Bias & Authors' judgement & Support for judgement \\
\hline $\begin{array}{l}\text { Allocation sequence gen- } \\
\text { eration (selection bias) }\end{array}$ & Low risk & $\begin{array}{l}\text { From a master list of children aged } 7-14 \text { years, groups of } 20 \text { families were se- } \\
\text { lected and assigned numbers and randomly selected for the control and inter- } \\
\text { vention groups }\end{array}$ \\
\hline $\begin{array}{l}\text { Allocation concealment } \\
\text { (selection bias) }\end{array}$ & Unclear risk & Not described \\
\hline $\begin{array}{l}\text { Baseline outcomes (selec- } \\
\text { tion bias) }\end{array}$ & Low risk & Outcomes were not imbalanced at baseline \\
\hline
\end{tabular}


Lewis 1991 (Continued)

\begin{tabular}{|c|c|c|}
\hline $\begin{array}{l}\text { Baseline characteristics } \\
\text { (selection bias) }\end{array}$ & High risk & $\begin{array}{l}\text { Some baseline differences were apparent (both parents at home, education } \\
\text { and employment status of mother and father) }\end{array}$ \\
\hline
\end{tabular}

$\begin{array}{ll}\begin{array}{l}\text { Incomplete outcome data } \\ \text { (attrition bias) }\end{array} & \text { Low risk } \\ \text { All outcomes } & \begin{array}{l}\text { Only } 73.2 \% \text { of mothers and } 59 \% \text { of fathers attended all } 4 \text { sessions in the inter- } \\ \text { vention group and } 62 \% \text { of mothers and } 49 \% \text { of fathers attended all } 3 \text { sessions } \\ \text { in the control group. However, pre- and post-test data were available for al- } \\ \text { most all parents. No intention-to-treat analysis was explicitly reported, but } \\ \text { data were reported for each participant in the final analysis for some, but not } \\ \text { all, outcomes despite attendance at the educational programme being incom- } \\ \text { plete }\end{array}\end{array}$

\begin{tabular}{|c|c|c|}
\hline $\begin{array}{l}\text { Blinding (performance } \\
\text { bias and detection bias) } \\
\text { All outcomes }\end{array}$ & High risk & $\begin{array}{l}\text { Participants and clinicians were not blinded; it is unclear if the trained inter- } \\
\text { viewers were blinded. The subjective nature of the outcomes measured (by } \\
\text { self-reported questionnaire) means this may have introduced bias }\end{array}$ \\
\hline
\end{tabular}

\begin{tabular}{lll}
\hline $\begin{array}{l}\text { Contamination (perfor- } \\
\text { mance bias) }\end{array}$ & High risk & $\begin{array}{l}\text { There was nothing to prevent participants in intervention and control groups } \\
\text { from interacting with each other and sharing knowledge }\end{array}$ \\
\hline $\begin{array}{l}\text { Selective reporting (re- } \\
\text { porting bias) }\end{array}$ & Low risk & All outcomes detailed in the methods were reported in the results. \\
\hline Other bias & Low risk & No other potential sources of risk of bias identified \\
\hline
\end{tabular}

\section{Modi 2016}

Methods Study type: Randomised controlled trial (but only for some participants, see Notes)

Duration of study: 3 months follow-up post-intervention

Population type: Children aged 2-12 years and their caregivers
Setting: New-onset seizure clinic in a Midwestern children's hospital, USA
Age, mean (SD) of children: $7.6(3.0)$
Male children: $33 / 50(66.0 \%)$
Health status: All children had new-onset epilepsy. $18 / 50(36.0 \%)$ of children had a seizure 3 month pri-
or to assessment
Most caregivers were parents of the children (mothers: $42 / 50[84.0 \%]) ;$ fathers: $5 / 50[10.0 \%])$

Interventions Non-randomised maintenance 'high adherence' group: participants with high ( $\geq 95 \%)$ antiepileptic drug adherence were not randomised but received five study visits (see Notes below) $(n=22)$

Randomised experimental group: Supporting Treatment Adherence Regimen (STAR), which included 4 face-to-face and 2 telephone problem-solving sessions over 8 weeks $(n=12)$

Randomised control: treatment as usual (TAU) $(n=11)$

Outcomes

Seizure activity (absence/presence), seizure type, antiepileptic drug prescription and changes to the regimen over time (medical chart review); daily antiepileptic drug adherence (Medication Event Monitoring Systems Track Cap) and adherence rates calculated from these data; knowledge about the medical and social aspects of epilepsy (Epilepsy Knowledge Questionnaire); medication management by caregivers of children with epilepsy (Pediatric Epilepsy Medication Self-Management Questionnaire); parental responses and perceptions related to seizures (Parent response to child illness questionnaire); caregiver feasibility and acceptability of the STAR intervention (study-specific questionnaire)

Data were recorded at baseline then across 2-week intervals (coinciding with intervention sessions): 24 weeks, 4-6 weeks, 6-8 weeks, 8-10 weeks, 10-12 weeks and 3-months follow-up post-intervention 
Modi 2016 (Continued)

Notes

At study entry, participants were assessed for antiepileptic drug adherence. After a 30-day monitoring period, participants were either followed due to good adherence ( $\geq 95 \%$; high adherence group) or randomised into one of two groups (<95\%; TAU or STAR intervention). In addition to the 30-day monitoring period, participants with good adherence had two additional opportunities to be randomised over the next 6 months. Similar to their 1-month run-in period, if adherence fell below $95 \%$ at the 3- or 6 month assessment period, the family was randomised to TAU or STAR.

Published data, no unpublished data sought

\section{Risk of bias}

\begin{tabular}{|c|c|c|}
\hline Bias & Authors' judgement & Support for judgement \\
\hline $\begin{array}{l}\text { Allocation sequence gen- } \\
\text { eration (selection bias) }\end{array}$ & Low risk & $\begin{array}{l}\text { Block randomisation used and participants stratified according to their treat- } \\
\text { ment compliance in the preceding months }\end{array}$ \\
\hline $\begin{array}{l}\text { Allocation concealment } \\
\text { (selection bias) }\end{array}$ & Unclear risk & $\begin{array}{l}\text { The allocation process was not described. It is noted that the randomisation } \\
\text { list was generated by the first author and held by a research assistant indepen- } \\
\text { dent of the study to reduce bias }\end{array}$ \\
\hline $\begin{array}{l}\text { Baseline outcomes (selec- } \\
\text { tion bias) }\end{array}$ & Unclear risk & $\begin{array}{l}\text { Initial measurements made in weeks } 1-2 \text {. The outcomes pertain to small group } \\
\text { and not possible to draw conclusions if there any differences which may bias } \\
\text { the results from the study }\end{array}$ \\
\hline $\begin{array}{l}\text { Baseline characteristics } \\
\text { (selection bias) }\end{array}$ & Unclear risk & $\begin{array}{l}\text { While percentage differences between treatment arms at baseline were appar- } \\
\text { ent, the numbers of participants were small making it difficult to draw conclu- } \\
\text { sions whether these apparent differences may bias the results from the study }\end{array}$ \\
\hline $\begin{array}{l}\text { Incomplete outcome data } \\
\text { (attrition bias) } \\
\text { All outcomes }\end{array}$ & High risk & $\begin{array}{l}\text { Study withdrawal and loss to follow up occurred in } 3 / 11(27.2 \%) \text { of instances in } \\
\text { the STAR group }\end{array}$ \\
\hline $\begin{array}{l}\text { Blinding (performance } \\
\text { bias and detection bias) } \\
\text { All outcomes }\end{array}$ & Unclear risk & $\begin{array}{l}\text { None of the participants, clinicians or assessors appeared to have been blind- } \\
\text { ed. However, some of the outcomes reported were derived from medical chart } \\
\text { reviews and so less likely to be prone to bias from a lack of blinding; other out- } \\
\text { comes measured via questionnaire were however prone to bias }\end{array}$ \\
\hline $\begin{array}{l}\text { Contamination (perfor- } \\
\text { mance bias) }\end{array}$ & Low risk & Limited potential of bias as face to face intervention \\
\hline $\begin{array}{l}\text { Selective reporting (re- } \\
\text { porting bias) }\end{array}$ & Low risk & $\begin{array}{l}\text { All outcomes detailed in the methods were reported in the results although } \\
\text { some outcomes were only reported in detail in a supplementary appendix }\end{array}$ \\
\hline Other bias & Low risk & No other potential sources of risk of bias identified \\
\hline
\end{tabular}

Pfäfflin 2012

Methods Study type: Controlled before-and-after study

Duration of study: 3 months follow-up

Participants
Setting: 9 epilepsy centres in Germany and Switzerland
Age, mean (SD) [range] of children: Experimental 9.7 (3.2) [0.1-12.0]; Control 9.6 (3.0) [1.0-11.0]
Male children: Experimental 40.0\%; Control 51.9\%


Pfäfflin 2012 (Continued)

Health status: Approximately half of all participants had comorbidities (Experimental 20/55 [56.6\%];

Control 14/48 [51.9\%]).

Seizures within the last 3 months: Experimental 26/39 (66.7\%); Control 16/25 (64.0\%)

Seizures at baseline were commonly reported daily (Experimental $8 / 39$ [20.5\%]; Control 6/25 [24.0\%])

or weekly (Experimental 4/39 [10.3\%]; Control 5/25 [20.0\%])

Mean (SD) age at onset of epilepsy: Experimental 4.4 (3.0); Control: 5.1 (3.3)

Age, mean (SD) [range] of parents: Experimental 40.1 (5.8) [35-57]; Control 37.6 (4.7) [26-49]

Male parents: Experimental 36.3\%; Control 41.7\%

Parents without final educational qualification: Experimental 1.8\%; Control 6.3\%

Parents who were employed: Experimental $67.3 \%$; Control $58.3 \%$

$\begin{array}{ll}\text { Interventions } & \text { Experimental group: Modular Education Programme Epilepsy for Families (FAMOSES) (children, } \mathrm{n}=31 ; \\ \text { parents, } \mathrm{n}=55) \\ \text { Control: waiting-list control (children, } \mathrm{n}=19 \text {; parents, } \mathrm{n}=48 \text { ) }\end{array}$

Outcomes Epilepsy-specific knowledge; coping with epilepsy; adaption to epilepsy; anxiety; seizure management including parental abilities to deal with child's seizures; seizure frequency and satisfaction with drug therapy; school absenteeism

All outcomes measured at baseline and 3-months follow-up

Notes

Aspects of the same evaluation of the same intervention previously reported (in German) by Rau 2006

Published data, no unpublished data sought

\section{Risk of bias}

\begin{tabular}{lll}
\hline Bias & Authors' judgement & Support for judgement \\
\hline $\begin{array}{l}\text { Allocation sequence gen- } \\
\text { eration (selection bias) }\end{array}$ & High risk & Controlled before-and-after study \\
\hline $\begin{array}{l}\text { Allocation concealment } \\
\text { (selection bias) }\end{array}$ & High risk & Controlled before-and-after study \\
\hline $\begin{array}{l}\text { Baseline outcomes (selec- } \\
\text { tion bias) }\end{array}$ & Unclear risk & $\begin{array}{l}\text { For a number of outcomes (epilepsy knowledge ('knowledge'), adaptation } \\
\text { to epilepsy, rules and limitations: attendance, impact of epilepsy), scores } \\
\text { were notably different between groups at baseline, all in favour of the control } \\
\text { group; in the earlier report by Rau 2006, no discussion about how baseline po- } \\
\text { tential differences might affect the result of the study before the data were } \\
\text { analysed; however, in the later report by Pfäfflin 2012, an analysis of co-vari- } \\
\text { ance (ANCOVA) was performed with 'knowledge at follow-up' as dependent } \\
\text { variable and 'knowledge at baseline' as covariate confirmed a statistically sig- } \\
\text { nificant group effect (control vs treatment) at follow-up after adjustment for } \\
\text { baseline values }\end{array}$ \\
\hline
\end{tabular}

Baseline characteristics High risk
(selection bias)

(selection bias)
A number of baseline demographic differences were apparent between the 2 groups (\% mothers, education and employment status of parents, \% girls and educational level of children)
Incomplete outcome data High risk

(attrition bias)

All outcomes
Only $71.4 \%$ of children and $64.7 \%$ of adults completed the postprogramme evaluation questionnaire and so were included in the analysis. Information on the number of participants lost to follow-up was not provided for adults by treatment group. For children, the dropout rate in the control group was $40.6 \%$ and in the intervention group was $18.4 \%$. Children with other conditions were significantly more common among the non-responders. No details were given of how investigators accounted for dropouts, but only participants completing 


\begin{tabular}{|c|c|c|}
\hline $\begin{array}{l}\text { Blinding (performance } \\
\text { bias and detection bias) } \\
\text { All outcomes }\end{array}$ & High risk & $\begin{array}{l}\text { None of the participants, clinicians or assessors appear to have been blinded. } \\
\text { The subjective nature of the outcomes measured (all by self-reported ques- } \\
\text { tionnaire) may have introduced bias }\end{array}$ \\
\hline $\begin{array}{l}\text { Contamination (perfor- } \\
\text { mance bias) }\end{array}$ & High risk & $\begin{array}{l}\text { Families were consecutively allocated to the treatment and control groups } \\
\text { and so there was nothing to prevent participants in intervention and control } \\
\text { groups from interacting with each other and sharing knowledge }\end{array}$ \\
\hline $\begin{array}{l}\text { Selective reporting (re- } \\
\text { porting bias) }\end{array}$ & Low risk & All outcomes detailed in the methods were reported in the results \\
\hline Other bias & Low risk & No other potential sources of risk of bias identified \\
\hline
\end{tabular}

Tieffenberg 2000

\begin{tabular}{|c|c|}
\hline Methods & $\begin{array}{l}\text { Study type: Randomised controlled trial } \\
\text { Duration of study: 1-year follow-up }\end{array}$ \\
\hline Participants & $\begin{array}{l}\text { Population type: Children (aged } 6-15 \text { years) with asthma }(n=188 \text { ) or epilepsy } n=167 \text { ) and their parents } \\
\text { (asthma, } n=188 \text {; epilepsy, } n=167 \text { ) } \\
\text { Setting: Community based programme in Buenos Aires, Argentina } \\
\text { Limited baseline information was reported for this study. Of patients with epilepsy, the mean }(S D) \\
\text { number of seizures within the last } 12 \text { months was } 0.80(1.46) \text { in the experimental group and } 0.49(1.15) \\
\text { in the control group }\end{array}$ \\
\hline
\end{tabular}

\begin{tabular}{ll}
\hline Interventions & Experimental: ACINDES: a child-centred training programme $(n=103)$ \\
Control: routine care without additional training received by experimental arm participants $(n=64)$
\end{tabular}

Outcomes

Knowledge, beliefs, attitudes and behaviours of the children; parental knowledge, fear of child death; clinical outcomes including seizure frequency and clinic attendance

Children and parents were interviewed before the program and 6 and 12 months after the program

\begin{tabular}{lll}
\hline Notes & Published data, no unpublished data sought \\
\hline Risk of bias & \\
\hline Bias & Authors' judgement & Support for judgement \\
\hline $\begin{array}{l}\text { Allocation sequence gen- } \\
\text { eration (selection bias) }\end{array}$ & Unclear risk & $\begin{array}{l}\text { The details of randomisation including the 'clustering techniques' used were } \\
\text { not reported }\end{array}$ \\
\hline $\begin{array}{l}\text { Allocation concealment } \\
\text { (selection bias) }\end{array}$ & Unclear risk & No details of how participants were allocated was provided \\
\hline $\begin{array}{l}\text { Baseline outcomes (selec- } \\
\text { tion bias) }\end{array}$ & Low risk & No baseline differences between groups were reported \\
\hline $\begin{array}{l}\text { Baseline characteristics } \\
\text { (selection bias) }\end{array}$ & Unclear risk & Baseline characteristics were not presented \\
\hline
\end{tabular}


Tieffenberg 2000 (Continued)

Incomplete outcome data High risk For those children with epilepsy, $13.6 \%$ of children were lost to follow-up in (attrition bias) the intervention group and $29.7 \%$ in the control group. No details were provid-

All outcomes ed of families lost to follow-up, but reasons for non-attendance were provided. No details were given of how drop-outs were accounted for. No intention-totreat analysis was reported

\begin{tabular}{|c|c|c|}
\hline $\begin{array}{l}\text { Blinding (performance } \\
\text { bias and detection bias) } \\
\text { All outcomes }\end{array}$ & Unclear risk & $\begin{array}{l}\text { None of the participants, clinicians or assessors appeared to have been blind- } \\
\text { ed. However, some of the outcomes reported were derived from hospital and } \\
\text { school records and so less likely to be prone to bias from a lack of blinding; } \\
\text { other outcomes measured via questionnaire were however prone to bias }\end{array}$ \\
\hline
\end{tabular}

\begin{tabular}{|c|c|c|}
\hline $\begin{array}{l}\text { Contamination (perfor- } \\
\text { mance bias) }\end{array}$ & High risk & $\begin{array}{l}\text { There was a possibility of contamination in both groups as randomisation was } \\
\text { not conducted by an independent centre }\end{array}$ \\
\hline
\end{tabular}

\begin{tabular}{|c|c|c|}
\hline $\begin{array}{l}\text { Selective reporting (re- } \\
\text { porting bias) }\end{array}$ & Low risk & $\begin{array}{l}\text { All broad outcome types detailed in the methods were reported in the results. } \\
\text { However, it is not clear if all the outcomes relating to knowledge, beliefs, at- } \\
\text { titudes and behaviours were reported. For example, in the group of children } \\
\text { with asthma, results from an outcome relating to communication between } \\
\text { physicians and children with asthma is reported. It is unclear if a similar out- } \\
\text { come was measured for epilepsy. }\end{array}$ \\
\hline
\end{tabular}

Other bias Low risk No other potential sources of risk of bias identified

\section{Characteristics of excluded studies [ordered by study ID]}

\begin{tabular}{ll}
\hline Study & Reason for exclusion \\
\hline Austin 2002 & Pre- and post-test feasibility study lacking a control group \\
\hline Hallfahrt 2007 & Duplicate of included study containing no new data (Jantzen 2009) \\
\hline Ibinda 2014 & $\begin{array}{l}\text { Also includes adults and mean age of participants } \geq 18 \text { years so will be included in review update of } \\
\text { interventions for adults }\end{array}$ \\
\hline Li 2013 & $\begin{array}{l}\text { Also includes adults and mean age of participants } \geq 18 \text { years so will be included in review update of } \\
\text { interventions for adults }\end{array}$ \\
\hline Mar 2005 & Audit of documentation and data recording \\
\hline Modi 2013 & $\begin{array}{l}\text { Pilot feasibility study, small sample size ( } \mathrm{N}=8 \text { ) and intervention has now been fully evaluated by } \\
\text { Modi } 2016 \text { which is included in the current review }\end{array}$ \\
\hline Price 2004 & $\begin{array}{l}\text { Before-and-after (pre- and post-test) design. Study measured knowledge and skills of educators re- } \\
\text { lated to seizure management. No participant-related outcomes }\end{array}$ \\
\hline Snead 2004 & \begin{tabular}{l} 
No control group \\
\hline
\end{tabular} \\
\hline
\end{tabular}

Characteristics of studies awaiting assessment [ordered by study ID] 
NCT02349529

\begin{tabular}{|c|c|}
\hline Methods & Exploratory open-label randomised controlled trial \\
\hline Participants & 200 children and adolescents with epilepsy, aged $12-17$ years \\
\hline Interventions & $\begin{array}{l}\text { Experimental group: psychosocial social learning group intervention, facilitated by an epilepsy } \\
\text { nurse specialist and clinical psychologist, using a cognitive behaviour therapy approach, aimed at } \\
\text { increasing awareness of how epilepsy may impact upon thoughts, feelings and activities and to de- } \\
\text { velop strategies for improved psychological adjustment } \\
\text { Control: waiting-list control }\end{array}$ \\
\hline Outcomes & $\begin{array}{l}\text { Primary: quality of life at baseline, completion of intervention, and at 3- and 6-month postgroup } \\
\text { completion, as measured via the Glasgow Epilepsy Outcome Scale for Young Persons (GEOS-YP) } \\
\text { and Paediatric Quality of Life Inventory (PedsQL) } \\
\text { Secondary: distress measured by the Paediatric Index of Emotional Distress (PIED) }\end{array}$ \\
\hline Notes & $\begin{array}{l}\text { Study commenced February } 2015 \\
\text { Estimated study completion date: April } 2016 \\
\text { Estimated primary completion date: April } 2016 \text { (final data collection date for primary outcome } \\
\text { measure) } \\
\text { Principal investigator: Liam Dorris, BSc (Hons), DClinPsy, NHS Greater Glasgow and Clyde } \\
\text { The aim of the study is to establish a standard manualised group intervention that can be used } \\
\text { throughout the UK which aims to: establish the effectiveness and desirability of this approach; im- } \\
\text { prove the overall quality of life, psychological health and social integration of young people with } \\
\text { epilepsy; and to improve epilepsy knowledge and self-management skills aimed at maximising } \\
\text { seizure control and overall management. }\end{array}$ \\
\hline
\end{tabular}

Characteristics of ongoing studies [ordered by study ID]

\section{IRCT2015060122514N1}

\begin{tabular}{ll}
\hline Trial name or title & IRCT2015060122514N1 \\
\hline Methods & Single-blind randomised clinical trial, with 3 arms \\
\hline Participants & $\begin{array}{l}90 \text { adolescents in the age range 12-18 years who are registered with the Iranian Epilepsy Associa- } \\
\text { tion }\end{array}$ \\
\hline
\end{tabular}

Interventions herence to the mation based on short message service (SMS) and workshop on self-efficacy and workshop will include slide show, discussion and question and answer exchange between researchers and patients and will cover the following topics.

- Sleeping

- Medication dosage

- Time for taking medicine

- Side effects of medications

- Continuation of medicine

- Not to take other medicine without consulting with a doctor

- Avoidance of stimuli and stress

- Exercises and activities 
Five self-care education pamphlets will also be given to this group of patients at regular intervals over 3 months.

Participants in the SMS arm will be sent 48 SMS every 4 weeks for 3 months with a focus on discussion workshops.

Participants in the control group will not receive any education.

\begin{tabular}{ll}
\hline Outcomes & $\begin{array}{l}\text { Self-efficacy (Epilepsy Self-Efficacy Scale-33 Items questionnaire); adherence to the medication } \\
\text { regimen (8-item Morisky Medication Adherence Scale (MMAS-8)) }\end{array}$ \\
\hline Starting date & 23 July 2015 \\
\hline Contact information & Mohammad Ali Hoseini \\
\hline Notes & The website reports that recruitment is now complete. \\
& www.irct.ir/searchresult.php?id=22514\&number=1
\end{tabular}

\section{ADDITIONAL TABLES}

Table 1. Seizure frequency and severity

\begin{tabular}{llllll}
\hline Study & Study type & $\begin{array}{l}\text { Strategy de- } \\
\text { signed for }\end{array}$ & Outcome & $\begin{array}{l}\text { Outcome } \\
\text { time }\end{array}$ & Findings \\
\hline Pfäfflin 2012 & $\begin{array}{l}\text { Controlled be- } \\
\text { fore-and-after } \\
\text { study }\end{array}$ & $\begin{array}{l}\text { Children and par- } \\
\text { ents (FAMOSES) }\end{array}$ & $\begin{array}{l}\text { Seizure fre- } \\
\text { quency }\end{array}$ & 3 months & $\begin{array}{l}\text { No statistically significant differences } \\
\text { between groups }(\mathrm{P}=0.397)\end{array}$ \\
\hline $\begin{array}{l}\text { Tieffenberg } \\
2000\end{array}$ & RCT & $\begin{array}{l}\text { Children and par- } \\
\text { ents (ACINDES) }\end{array}$ & $\begin{array}{l}\text { Number of } \\
\text { epileptic } \\
\text { seizures }\end{array}$ & 12 months & $\begin{array}{l}\text { Statistically significant difference in the } \\
\text { number of epileptic seizures between } \\
\text { groups in favour of the intervention (P }= \\
0.026)\end{array}$ \\
\hline
\end{tabular}

Table 2. Appropriateness and volume of medication prescribed (including evidence of drug toxicity)

\begin{tabular}{|c|c|c|c|c|c|}
\hline Study & Study type & $\begin{array}{l}\text { Strategy de- } \\
\text { signed for }\end{array}$ & Outcome & $\begin{array}{l}\text { Outcome } \\
\text { time }\end{array}$ & Findings \\
\hline Jantzen 2009 & $\begin{array}{l}\text { Controlled be- } \\
\text { fore-and-after } \\
\text { study }\end{array}$ & $\begin{array}{l}\text { Children, } \\
\text { adolescents } \\
\text { and parents } \\
\text { (FLIP\&FLAP) }\end{array}$ & $\begin{array}{l}\text { Child's self-man- } \\
\text { agement skills } \\
\text { (i.e. taking med- } \\
\text { ication) }\end{array}$ & 6 months & $\begin{array}{l}\text { Statistically significant difference be- } \\
\text { tween groups in relation to parents re- } \\
\text { porting improved self-management } \\
\text { skills (i.e. taking medication) in favour } \\
\text { of the intervention versus control }(P< \\
0.001)\end{array}$ \\
\hline Modi 2016 & $\mathrm{RCT}$ & $\begin{array}{l}\text { Children and } \\
\text { parents (STAR) }\end{array}$ & $\begin{array}{l}\text { Antiepileptic } \\
\text { drug adherence }\end{array}$ & 3 months & $\begin{array}{l}\text { No statistically significant differences } \\
\text { between groups ( } P \text { value not reported) }\end{array}$ \\
\hline Pfäfflin 2012 & $\begin{array}{l}\text { Controlled be- } \\
\text { fore-and-after } \\
\text { study }\end{array}$ & $\begin{array}{l}\text { Children } \\
\text { and parents } \\
\text { (FAMOSES) }\end{array}$ & $\begin{array}{l}\text { Tolerability } \\
\text { and efficacy of }\end{array}$ & 3 months & $\begin{array}{l}\text { No statistically significant difference in } \\
\text { either in the intervention group nor in } \\
\text { the control group }(P>0.2)\end{array}$ \\
\hline
\end{tabular}


Table 2. Appropriateness and volume of medication prescribed (including evidence of drug toxicity) (Continued)

antiepileptic

drug

Table 3. Knowledge of information and advice received from professionals

\begin{tabular}{|c|c|c|c|c|c|}
\hline Study & Study type & $\begin{array}{l}\text { Strategy de- } \\
\text { signed for }\end{array}$ & Outcome & $\begin{array}{l}\text { Outcome } \\
\text { time }\end{array}$ & Findings \\
\hline Jantzen 2009 & $\begin{array}{l}\text { Controlled be- } \\
\text { fore-and-after } \\
\text { study }\end{array}$ & $\begin{array}{l}\text { Children, } \\
\text { adolescents } \\
\text { and parents } \\
\text { (FLIP\&FLAP) }\end{array}$ & $\begin{array}{l}\text { Children's } \\
\text { knowledge of } \\
\text { epilepsy }\end{array}$ & 6 months & $\begin{array}{l}\text { Statistically significant improvement be- } \\
\text { tween groups in favour of the interven- } \\
\text { tion group }(P<0.001)\end{array}$ \\
\hline Jantzen 2009 & $\begin{array}{l}\text { Controlled be- } \\
\text { fore-and-after } \\
\text { study }\end{array}$ & $\begin{array}{l}\text { Children, } \\
\text { adolescents } \\
\text { and parents } \\
\text { (FLIP\&FLAP) }\end{array}$ & $\begin{array}{l}\text { Adolescents' } \\
\text { knowledge of } \\
\text { medical aspects }\end{array}$ & 6 months & $\begin{array}{l}\text { Statistically significant improvement be- } \\
\text { tween groups in favour of the interven- } \\
\text { tion group }(P<0.001)\end{array}$ \\
\hline Jantzen 2009 & $\begin{array}{l}\text { Controlled be- } \\
\text { fore-and-after } \\
\text { study }\end{array}$ & $\begin{array}{l}\text { Children, } \\
\text { adolescents } \\
\text { and parents } \\
\text { (FLIP\&FLAP) }\end{array}$ & $\begin{array}{l}\text { Parents' knowl- } \\
\text { edge of medical } \\
\text { aspects }\end{array}$ & 6 months & $\begin{array}{l}\text { Statistically significant improvement be- } \\
\text { tween groups in favour of the interven- } \\
\text { tion group }(P<0.05)\end{array}$ \\
\hline Jantzen 2009 & $\begin{array}{l}\text { Controlled be- } \\
\text { fore-and-after } \\
\text { study }\end{array}$ & $\begin{array}{l}\text { Children, } \\
\text { adolescents } \\
\text { and parents } \\
\text { (FLIP\&FLAP) }\end{array}$ & $\begin{array}{l}\text { Adolescents' } \\
\text { knowledge of so- } \\
\text { cial aspects }\end{array}$ & 6 months & $\begin{array}{l}\text { Differences not reported to be statistical- } \\
\text { ly significant between groups ( } P \text { value not } \\
\text { reported) }\end{array}$ \\
\hline Jantzen 2009 & $\begin{array}{l}\text { Controlled be- } \\
\text { fore-and-after } \\
\text { study }\end{array}$ & $\begin{array}{l}\text { Children, } \\
\text { adolescents } \\
\text { and parents } \\
\text { (FLIP\&FLAP) }\end{array}$ & $\begin{array}{l}\text { Parents' knowl- } \\
\text { edge of social as- } \\
\text { pects }\end{array}$ & 6 months & $\begin{array}{l}\text { Statistically significant improvement be- } \\
\text { tween groups in favour of the interven- } \\
\text { tion group }(P<0.001)\end{array}$ \\
\hline Jantzen 2009 & $\begin{array}{l}\text { Controlled be- } \\
\text { fore-and-after } \\
\text { study }\end{array}$ & $\begin{array}{l}\text { Children, } \\
\text { adolescents } \\
\text { and parents } \\
\text { (FLIP\&FLAP) }\end{array}$ & $\begin{array}{l}\text { Adolescents' } \\
\text { knowledge of } \\
\text { seizure triggers }\end{array}$ & 6 months & $\begin{array}{l}\text { Statistically significant improvement be- } \\
\text { tween groups in favour of the interven- } \\
\text { tion group }(P<0.05)\end{array}$ \\
\hline Jantzen 2009 & $\begin{array}{l}\text { Controlled be- } \\
\text { fore-and-after } \\
\text { study }\end{array}$ & $\begin{array}{l}\text { Children, } \\
\text { adolescents } \\
\text { and parents } \\
\text { (FLIP\&FLAP) }\end{array}$ & $\begin{array}{l}\text { Parents' knowl- } \\
\text { edge of seizure } \\
\text { triggers }\end{array}$ & 6 months & $\begin{array}{l}\text { Statistically significant improvement be- } \\
\text { tween groups in favour of the interven- } \\
\text { tion group }(P<0.001)\end{array}$ \\
\hline Jantzen 2009 & $\begin{array}{l}\text { Controlled be- } \\
\text { fore-and-after } \\
\text { study }\end{array}$ & $\begin{array}{l}\text { Children, } \\
\text { adolescents } \\
\text { and parents } \\
\text { (FLIP\&FLAP) }\end{array}$ & $\begin{array}{l}\text { Children's ability } \\
\text { to explain epilep- } \\
\text { sy to others }\end{array}$ & 6 months & $\begin{array}{l}\text { Differences not reported to be statistical- } \\
\text { ly significant between groups ( } P \text { value not } \\
\text { reported) }\end{array}$ \\
\hline Jantzen 2009 & $\begin{array}{l}\text { Controlled be- } \\
\text { fore-and-after } \\
\text { study }\end{array}$ & $\begin{array}{l}\text { Children, } \\
\text { adolescents } \\
\text { and parents } \\
\text { (FLIP\&FLAP) }\end{array}$ & $\begin{array}{l}\text { Adolescents' } \\
\text { ability to explain } \\
\text { epilepsy to oth- } \\
\text { ers }\end{array}$ & 6 months & $\begin{array}{l}\text { Differences not reported to be statistical- } \\
\text { ly significant between groups ( } P \text { value not } \\
\text { reported) }\end{array}$ \\
\hline Jantzen 2009 & $\begin{array}{l}\text { Controlled be- } \\
\text { fore-and-after } \\
\text { study }\end{array}$ & $\begin{array}{l}\text { Children, } \\
\text { adolescents }\end{array}$ & $\begin{array}{l}\text { Parents' ability } \\
\text { to explain epilep- } \\
\text { sy to others }\end{array}$ & 6 months & $\begin{array}{l}\text { Statistically significant improvement be- } \\
\text { tween groups in favour of the interven- } \\
\text { tion group }(P<0.001)\end{array}$ \\
\hline
\end{tabular}


Table 3. Knowledge of information and advice received from professionals (Continued)

and parents

(FLIP\&FLAP)

\begin{tabular}{lll}
\hline Lewis $1990 \quad$ RCT & $\begin{array}{l}\text { Children and } \\
\text { parents (CEP) }\end{array}$ & $\begin{array}{l}\text { "What were } \\
\text { the important } \\
\text { things that you } \\
\text { learned?" }\end{array}$
\end{tabular}

\begin{tabular}{lllll}
\hline Lewis 1991 & RCT & $\begin{array}{l}\text { Children and } \\
\text { parents (CEP) }\end{array}$ & $\begin{array}{l}\text { "What were } \\
\text { the important } \\
\text { things that you } \\
\text { learned?" }\end{array}$ & 5 months \\
\hline Lewis 1991 & RCT & $\begin{array}{l}\text { Children and } \\
\text { parents (CEP) }\end{array}$ & $\begin{array}{l}\text { Importance of } \\
\text { medicines* }\end{array}$ & 5 months \\
& &
\end{tabular}

Children in the intervention group were more likely to report generic gain in knowledge than those in the control group (mean: $64 \%$ with intervention versus $47 \%$ with control; $P<0.01$ )

\begin{tabular}{llll}
\hline Lewis 1990 & RCT & $\begin{array}{l}\text { Children and } \\
\text { parents (CEP) }\end{array}$ & $\begin{array}{l}\text { Importance of } \\
\text { taking medicines } \\
\text { exactly as pre- } \\
\text { scribed }\end{array}$
\end{tabular}

\begin{tabular}{|c|c|c|c|c|c|}
\hline Lewis 1991 & $\mathrm{RCT}$ & $\begin{array}{l}\text { Children and } \\
\text { parents (CEP) }\end{array}$ & $\begin{array}{l}\text { Importance of } \\
\text { taking medicines } \\
\text { exactly as pre- } \\
\text { scribed }\end{array}$ & 5 months & $\begin{array}{l}\text { Differences 'not significant' between } \\
\text { groups in the percentage of parents re- } \\
\text { sponding correctly ( } P \text { value not reported) }\end{array}$ \\
\hline Lewis 1990 & $\mathrm{RCT}$ & $\begin{array}{l}\text { Children and } \\
\text { parents (CEP) }\end{array}$ & $\begin{array}{l}\text { Inappropriate } \\
\text { to have objects } \\
\text { in mouth during } \\
\text { seizure }\end{array}$ & 5 months & $\begin{array}{l}\text { Statistically significant differences be- } \\
\text { tween groups in the percentage of chil- } \\
\text { dren responding correctly (mean baseline } \\
\text { to five months: } 40.7 \% \text { to } 71.5 \% \text { with inter- } \\
\text { vention versus } 44.3 \% \text { to } 52.2 \% \text { with con- } \\
\text { trol; } P=0.002 \text { ) }\end{array}$ \\
\hline Lewis 1991 & $\mathrm{RCT}$ & $\begin{array}{l}\text { Children and } \\
\text { parents (CEP) }\end{array}$ & $\begin{array}{l}\text { Inappropriate } \\
\text { to have objects } \\
\text { in mouth during } \\
\text { seizure }\end{array}$ & 5 months & $\begin{array}{l}\text { Differences 'not significant' between } \\
\text { groups in the percentage of parents re- } \\
\text { sponding correctly ( } P \text { value not reported) }\end{array}$ \\
\hline Lewis 1990 & $\mathrm{RCT}$ & $\begin{array}{l}\text { Children and } \\
\text { parents (CEP) }\end{array}$ & $\begin{array}{l}\text { Inappropriate to } \\
\text { restrain during } \\
\text { seizure }\end{array}$ & 5 months & $\begin{array}{l}\text { Statistically significant differences be- } \\
\text { tween groups in the percentage of chil- } \\
\text { dren responding correctly (mean baseline } \\
\text { to five months: } 34.9 \% \text { to } 79.7 \% \text { with inter- } \\
\text { vention versus } 33.6 \% \text { to } 46.0 \% \text { with con- } \\
\text { trol; } P=0.001 \text { ) }\end{array}$ \\
\hline Lewis 1991 & $\mathrm{RCT}$ & $\begin{array}{l}\text { Children and } \\
\text { parents (CEP) }\end{array}$ & $\begin{array}{l}\text { Inappropriate to } \\
\text { restrain during } \\
\text { seizure }\end{array}$ & 5 months & $\begin{array}{l}\text { Differences 'not significant' between } \\
\text { groups in the percentage of parents re- } \\
\text { sponding correctly ( } P \text { value not reported) }\end{array}$ \\
\hline Lewis 1990 & $\mathrm{RCT}$ & $\begin{array}{l}\text { Children and } \\
\text { parents (CEP) }\end{array}$ & $\begin{array}{l}\text { Knowledge that } \\
\text { seizures start in } \\
\text { the brain }\end{array}$ & 5 months & $\begin{array}{l}\text { Differences 'not significant' between } \\
\text { groups in the percentage of parents re- } \\
\text { sponding correctly ( } P \text { value not reported) }\end{array}$ \\
\hline
\end{tabular}


Table 3. Knowledge of information and advice received from professionals (Continued)

\begin{tabular}{|c|c|c|c|c|c|}
\hline Lewis 1991 & $\mathrm{RCT}$ & $\begin{array}{l}\text { Children and } \\
\text { parents (CEP) }\end{array}$ & $\begin{array}{l}\text { Knowledge that } \\
\text { seizures start in } \\
\text { the brain }\end{array}$ & 5 months & $\begin{array}{l}\text { Differences 'not significant' between } \\
\text { groups in the percentage of parents re- } \\
\text { sponding correctly (P value not reported) }\end{array}$ \\
\hline Lewis 1990 & $\mathrm{RCT}$ & $\begin{array}{l}\text { Children and } \\
\text { parents (CEP) }\end{array}$ & $\begin{array}{l}\text { Loss of sleep can } \\
\text { trigger seizures }\end{array}$ & 5 months & $\begin{array}{l}\text { Differences 'not significant' between } \\
\text { groups in the percentage of parents re- } \\
\text { sponding correctly ( } P \text { value not reported) }\end{array}$ \\
\hline Lewis 1991 & $\mathrm{RCT}$ & $\begin{array}{l}\text { Children and } \\
\text { parents (CEP) }\end{array}$ & $\begin{array}{l}\text { Loss of sleep can } \\
\text { trigger seizures }\end{array}$ & 5 months & $\begin{array}{l}\text { Statistically significant differences be- } \\
\text { tween groups in the percentage of par- } \\
\text { ents responding correctly (mean baseline } \\
\text { to five months: } 62.7 \% \text { to } 50.3 \% \text { with inter- } \\
\text { vention versus } 66.3 \% \text { to } 65.2 \% \text { with con- } \\
\text { trol; } P=0.005 \text { ) }\end{array}$ \\
\hline
\end{tabular}

\begin{tabular}{lll}
\hline Lewis $1990 \quad$ RCT & Children and & Not required to 5 months \\
& parents (CEP) & $\begin{array}{l}\text { visit emergency } \\
\text { department after } \\
\text { seizure }\end{array}$
\end{tabular}

Statistically significant differences between groups in the percentage of children responding correctly (mean baseline to five months: $30.9 \%$ to $78.1 \%$ with intervention versus $29.2 \%$ to $52.2 \%$ with control; $\mathrm{P}=0.001$ )

\begin{tabular}{|c|c|c|c|c|c|}
\hline Lewis 1991 & RCT & $\begin{array}{l}\text { Children and } \\
\text { parents (CEP) }\end{array}$ & $\begin{array}{l}\text { Not required to } \\
\text { visit emergency } \\
\text { department after } \\
\text { seizure }\end{array}$ & 5 months & $\begin{array}{l}\text { Differences 'not significant' between } \\
\text { groups in the percentage of parents re- } \\
\text { sponding correctly ( } P \text { value not reported }\end{array}$ \\
\hline
\end{tabular}

\begin{tabular}{|c|c|c|c|c|c|}
\hline Lewis 1990 & $\mathrm{RCT}$ & $\begin{array}{l}\text { Children and } \\
\text { parents (CEP) }\end{array}$ & $\begin{array}{l}\text { Positive effects } \\
\text { of participation } \\
\text { in sports }\end{array}$ & 5 months & $\begin{array}{l}\text { Differences 'not significant' between } \\
\text { groups in the percentage of parents re- } \\
\text { sponding correctly ( } P \text { value not reported) }\end{array}$ \\
\hline
\end{tabular}

\begin{tabular}{|c|c|c|c|c|c|}
\hline Lewis 1991 & RCT & $\begin{array}{l}\text { Children and } \\
\text { parents (CEP) }\end{array}$ & $\begin{array}{l}\text { Positive effects } \\
\text { of participation } \\
\text { in sports }\end{array}$ & 5 months & $\begin{array}{l}\text { Differences 'not significant' between } \\
\text { groups in the percentage of parents re- } \\
\text { sponding correctly (P value not reported) }\end{array}$ \\
\hline
\end{tabular}

\begin{tabular}{|c|c|c|c|c|c|}
\hline Lewis 1990 & $\mathrm{RCT}$ & $\begin{array}{l}\text { Children and } \\
\text { parents (CEP) }\end{array}$ & $\begin{array}{l}\text { Purpose of drug } \\
\text { blood levels to } \\
\text { monitor dosage }\end{array}$ & 5 months & $\begin{array}{l}\text { Differences 'not significant' between } \\
\text { groups in the percentage of parents re- } \\
\text { sponding correctly ( } P \text { value not reported) }\end{array}$ \\
\hline Lewis 1991 & $\mathrm{RCT}$ & $\begin{array}{l}\text { Children and } \\
\text { parents (CEP) }\end{array}$ & $\begin{array}{l}\text { Purpose of drug } \\
\text { blood levels to } \\
\text { monitor dosage }\end{array}$ & 5 months & $\begin{array}{l}\text { Statistically significant differences be- } \\
\text { tween groups in the percentage of par- } \\
\text { ents responding correctly (mean baseline } \\
\text { to five months: } 63.4 \% \text { to } 79.6 \% \text { with inter- } \\
\text { vention versus } 67.2 \% \text { to } 87.8 \% \text { with con- } \\
\text { trol; } P=0.04 \text { ) }\end{array}$ \\
\hline
\end{tabular}

\begin{tabular}{|c|c|c|c|c|c|}
\hline Lewis 1990 & $\mathrm{RCT}$ & $\begin{array}{l}\text { Children and } \\
\text { parents (CEP) }\end{array}$ & $\begin{array}{l}\text { Purpose of elec- } \\
\text { troencephalo- } \\
\text { gram (EEG) }\end{array}$ & 5 months & $\begin{array}{l}\text { Statistically significant differences be- } \\
\text { tween groups in the percentage of chil- } \\
\text { dren responding correctly (mean baseline } \\
\text { to five months: } 62.6 \% \text { to } 82.1 \% \text { with inter- } \\
\text { vention versus } 63.7 \% \text { to } 69.0 \% \text { with con- } \\
\text { trol; } P=0.02 \text { ) }\end{array}$ \\
\hline
\end{tabular}

\begin{tabular}{llll}
\hline Lewis 1991 & RCT & $\begin{array}{l}\text { Children and } \\
\text { parents (CEP) }\end{array}$ & $\begin{array}{l}\text { Purpose of elec- } \\
\text { troencephalo- } \\
\text { gram (EEG) }\end{array}$
\end{tabular}$\quad \begin{array}{ll}5 \text { months } & \begin{array}{l}\text { Statistically significant differences be- } \\
\text { tween groups in the percentage of par- } \\
\text { ents responding correctly (mean baseline } \\
\text { to five months: } 80.0 \% \text { to } 90.3 \% \text { with inter- }\end{array}\end{array}$


Table 3. Knowledge of information and advice received from professionals

(Continued)

vention versus $81.1 \%$ to $83.3 \%$ with control; $\mathrm{P}=0.05$ )

\begin{tabular}{llll}
\hline Lewis 1990 & RCT & $\begin{array}{l}\text { Children and } \\
\text { parents (CEP) }\end{array}$ & $\begin{array}{l}\text { Restriction of ac- } \\
\text { tivities should be } \\
\text { minimal }\end{array}$
\end{tabular}

Statistically significant differences between groups in the percentage of children responding correctly (mean baseline to five months: $58.5 \%$ to $86.2 \%$ with intervention versus $58.4 \%$ to $68.1 \%$ with control; $P=0.001$ )

\begin{tabular}{|c|c|c|c|c|c|}
\hline Lewis 1991 & $\mathrm{RCT}$ & $\begin{array}{l}\text { Children and } \\
\text { parents (CEP) }\end{array}$ & $\begin{array}{l}\text { Restriction of ac- } \\
\text { tivities should be } \\
\text { minimal }\end{array}$ & 5 months & $\begin{array}{l}\text { Differences 'not significant' between } \\
\text { groups in the percentage of parents re- } \\
\text { sponding correctly ( } P \text { value not reported) }\end{array}$ \\
\hline Modi 2016 & $\mathrm{RCT}$ & $\begin{array}{l}\text { Children } \\
\text { and parents } \\
\text { (STAR) }\end{array}$ & $\begin{array}{l}\text { Parents' knowl- } \\
\text { edge - Pediatric } \\
\text { Epilepsy Medica- } \\
\text { tion Self-Man- } \\
\text { agement Ques- } \\
\text { tionnaire }\end{array}$ & 3 months & $\begin{array}{l}\text { Statistically significant improved be- } \\
\text { tween groups in favour of the interven- } \\
\text { tion group }(P<0.05)\end{array}$ \\
\hline Modi 2016 & $\mathrm{RCT}$ & $\begin{array}{l}\text { Children } \\
\text { and parents } \\
\text { (STAR) }\end{array}$ & $\begin{array}{l}\text { Parents' knowl- } \\
\text { edge - Epilep- } \\
\text { sy Knowledge } \\
\text { Questionnaire }\end{array}$ & 3 months & $\begin{array}{l}\text { Statistically significant improved be- } \\
\text { tween groups in favour of the interven- } \\
\text { tion group }(P<0.01)\end{array}$ \\
\hline Pfäfflin 2012 & $\begin{array}{l}\text { Controlled be- } \\
\text { fore-and-after } \\
\text { study }\end{array}$ & $\begin{array}{l}\text { Children } \\
\text { and parents } \\
\text { (FAMOSES) }\end{array}$ & $\begin{array}{l}\text { Epilepsy knowl- } \\
\text { edge (epileptic } \\
\text { seizures always } \\
\text { cause death of } \\
\text { brain cells) }\end{array}$ & 3 months & $\begin{array}{l}\text { Statistically significant increase in par- } \\
\text { ents' knowledge between groups in } \\
\text { favour of the intervention }(P<0.001)\end{array}$ \\
\hline $\begin{array}{l}\text { Tieffenberg } \\
2000\end{array}$ & $\mathrm{RCT}$ & $\begin{array}{l}\text { Children and } \\
\text { parents (ACIN- } \\
\text { DES) }\end{array}$ & $\begin{array}{l}\text { Parents' knowl- } \\
\text { edge }\end{array}$ & 12 months & $\begin{array}{l}\text { Improved in the intervention group at } 12 \\
\text { months (from } 22 \% \text { to } 56 \% \text { ) compared to } \\
\text { control (from } 8 \% \text { to } 15 \% \text {, probability of } \\
\text { gain }=0.62 \text {, variance }=0.0026 \text { ), }\end{array}$ \\
\hline $\begin{array}{l}\text { Tieffenberg } \\
2000\end{array}$ & $\mathrm{RCT}$ & $\begin{array}{l}\text { Children and } \\
\text { parents (ACIN- } \\
\text { DES) }\end{array}$ & $\begin{array}{l}\text { Parents' fears } \\
\text { and anxieties }\end{array}$ & 12 months & $\begin{array}{l}\text { Improved in the intervention group at } \\
12 \text { months (from } 69 \% \text { to } 30 \% \text { for fear of } \\
\text { child's death) compared to no change } \\
\text { in the control group (from } 74 \% \text { to } 65 \% \text {, } \\
\text { probability of gain }=0.63 \text {, variance }= \\
0.0026 \text { ) }\end{array}$ \\
\hline
\end{tabular}

${ }^{\star}$ Not reported for children in Lewis 1990

Table 4. Health and quality of life (including side-effects of medication)

\begin{tabular}{|c|c|c|c|c|c|}
\hline Study & Study type & $\begin{array}{l}\text { Strategy de- } \\
\text { signed for }\end{array}$ & Outcome & $\begin{array}{l}\text { Outcome } \\
\text { time }\end{array}$ & Findings \\
\hline $\begin{array}{l}\text { Glueckauf } \\
2002\end{array}$ & $\begin{array}{l}\text { RCT (but with } \\
\text { failed ran- } \\
\text { domisation) }\end{array}$ & $\begin{array}{l}\text { Teenagers and } \\
\text { parents }\end{array}$ & $\begin{array}{l}\text { Self-perception } \\
\text { of severity of } \\
\text { family problems }\end{array}$ & 6 months & $\begin{array}{l}\text { At one week post-treatment and six } \\
\text { months follow-up, there were no statisti- } \\
\text { cally significant differences in outcome } \\
\text { measures between the intervention and } \\
\text { control groups of teenagers ( } P \text { value not } \\
\text { reported) }\end{array}$ \\
\hline
\end{tabular}


Table 4. Health and quality of life (including side-effects of medication) (Continued)

\begin{tabular}{|c|c|c|c|c|c|}
\hline $\begin{array}{l}\text { Glueckauf } \\
2002\end{array}$ & $\begin{array}{l}\text { RCT (but with } \\
\text { failed ran- } \\
\text { domisation) }\end{array}$ & $\begin{array}{l}\text { Teenagers and } \\
\text { parents }\end{array}$ & $\begin{array}{l}\text { Self-perception } \\
\text { of severity of } \\
\text { family problems }\end{array}$ & 6 months & $\begin{array}{l}\text { At one week post-treatment and six } \\
\text { months follow-up, there were no statisti- } \\
\text { cally significant differences in outcome } \\
\text { measures between the intervention and } \\
\text { control groups of teenagers (P value not } \\
\text { reported) }\end{array}$ \\
\hline
\end{tabular}

\begin{tabular}{|c|c|c|c|c|c|}
\hline $\begin{array}{l}\text { Glueckauf } \\
2002\end{array}$ & $\begin{array}{l}\text { RCT (but with } \\
\text { failed ran- } \\
\text { domisation) }\end{array}$ & $\begin{array}{l}\text { Teenagers and } \\
\text { parents }\end{array}$ & $\begin{array}{l}\text { Self-perception } \\
\text { of frequency of } \\
\text { family problems }\end{array}$ & 6 months & $\begin{array}{l}\text { At one week post-treatment and six } \\
\text { months follow-up, there were no statisti- } \\
\text { cally significant differences in outcome } \\
\text { measures between the intervention and } \\
\text { control groups of teenagers ( } P \text { value not } \\
\text { reported) }\end{array}$ \\
\hline
\end{tabular}

\begin{tabular}{|c|c|c|c|c|c|}
\hline $\begin{array}{l}\text { Glueckauf } \\
2002\end{array}$ & $\begin{array}{l}\text { RCT (but with } \\
\text { failed ran- } \\
\text { domisation) }\end{array}$ & $\begin{array}{l}\text { Teenagers and } \\
\text { parents }\end{array}$ & $\begin{array}{l}\text { Self-perception } \\
\text { of frequency of } \\
\text { family problems }\end{array}$ & 6 months & $\begin{array}{l}\text { At one week post-treatment and six } \\
\text { months follow-up, there were no statisti- } \\
\text { cally significant differences in outcome } \\
\text { measures between the intervention and } \\
\text { control groups of teenagers ( } P \text { value not } \\
\text { reported) }\end{array}$ \\
\hline
\end{tabular}

\begin{tabular}{|c|c|c|c|c|c|}
\hline $\begin{array}{l}\text { Glueckauf } \\
2002\end{array}$ & $\begin{array}{l}\text { RCT (but with } \\
\text { failed ran- } \\
\text { domisation) }\end{array}$ & $\begin{array}{l}\text { Teenagers and } \\
\text { parents }\end{array}$ & $\begin{array}{l}\text { Teenager's pro- } \\
\text { social behaviour } \\
\text { (in classroom } \\
\text { and home set- } \\
\text { tings) }\end{array}$ & 6 months & $\begin{array}{l}\text { At one week post-treatment and six } \\
\text { months follow-up, differences in out- } \\
\text { come measures as rated by parents were } \\
\text { significantly in favour of the intervention } \\
\text { group versus the control group }(P<0.001)\end{array}$ \\
\hline
\end{tabular}

\begin{tabular}{|c|c|c|c|c|c|}
\hline $\begin{array}{l}\text { Glueckauf } \\
2002\end{array}$ & $\begin{array}{l}\text { RCT (but with } \\
\text { failed ran- } \\
\text { domisation) }\end{array}$ & $\begin{array}{l}\text { Teenagers and } \\
\text { parents }\end{array}$ & $\begin{array}{l}\text { Teenager's pro- } \\
\text { social behaviour } \\
\text { (in classroom } \\
\text { and home set- } \\
\text { tings) }\end{array}$ & 6 months & $\begin{array}{l}\text { At one week post-treatment and six } \\
\text { months follow-up, differences in out- } \\
\text { come measures as rated by teachers were } \\
\text { significantly in favour of the intervention } \\
\text { group versus the control group }(P<0.001)\end{array}$ \\
\hline
\end{tabular}

\begin{tabular}{|c|c|c|c|c|c|}
\hline $\begin{array}{l}\text { Glueckauf } \\
2002\end{array}$ & $\begin{array}{l}\text { RCT (but with } \\
\text { failed ran- } \\
\text { domisation) }\end{array}$ & $\begin{array}{l}\text { Teenagers and } \\
\text { parents }\end{array}$ & $\begin{array}{l}\text { Teenager's prob- } \\
\text { lem behaviour } \\
\text { (in classroom } \\
\text { and home set- } \\
\text { tings) }\end{array}$ & 6 months & $\begin{array}{l}\text { At one week post-treatment and six } \\
\text { months follow-up, differences in out- } \\
\text { come measures as rated by parents were } \\
\text { significantly in favour of the intervention } \\
\text { group versus the control group }(P<0.001)\end{array}$ \\
\hline $\begin{array}{l}\text { Glueckauf } \\
2002\end{array}$ & $\begin{array}{l}\text { RCT (but with } \\
\text { failed ran- } \\
\text { domisation) }\end{array}$ & $\begin{array}{l}\text { Teenagers and } \\
\text { parents }\end{array}$ & $\begin{array}{l}\text { Teenager's prob- } \\
\text { lem behaviour } \\
\text { (in classroom } \\
\text { and home set- } \\
\text { tings) }\end{array}$ & 6 months & $\begin{array}{l}\text { At one week post-treatment and six } \\
\text { months follow-up, differences in out- } \\
\text { come measures as rated by teachers were } \\
\text { significantly in favour of the intervention } \\
\text { group versus the control group }(P<0.001)\end{array}$ \\
\hline Lewis 1990 & $\mathrm{RCT}$ & $\begin{array}{l}\text { Children and } \\
\text { parents (CEP) }\end{array}$ & $\begin{array}{l}\text { Social compe- } \\
\text { tency }\end{array}$ & 5 months & $\begin{array}{l}\text { Statistically significant differences be- } \\
\text { tween groups of children in social compe- } \\
\text { tency after scores were adjusted for pre- } \\
\text { test values, age and sex }(P<0.05) \text {. }\end{array}$ \\
\hline Lewis 1990 & $\mathrm{RCT}$ & $\begin{array}{l}\text { Children and } \\
\text { parents (CEP) }\end{array}$ & $\begin{array}{l}\text { Scholastic com- } \\
\text { petency }\end{array}$ & 5 months & $\begin{array}{l}\text { Differences 'not significant' between } \\
\text { children in the intervention and control } \\
\text { groups ( } P \text { value not reported) }\end{array}$ \\
\hline Lewis 1990 & $\mathrm{RCT}$ & $\begin{array}{l}\text { Children and } \\
\text { parents (CEP) }\end{array}$ & $\begin{array}{l}\text { Athletic compe- } \\
\text { tency }\end{array}$ & 5 months & $\begin{array}{l}\text { Differences 'not significant' between } \\
\text { children in the intervention and control } \\
\text { groups ( } P \text { value not reported) }\end{array}$ \\
\hline
\end{tabular}


Table 4. Health and quality of life (including side-effects of medication) (Continued)

\begin{tabular}{|c|c|c|c|c|c|}
\hline Lewis 1990 & $\mathrm{RCT}$ & $\begin{array}{l}\text { Children and } \\
\text { parents (CEP) }\end{array}$ & $\begin{array}{l}\text { Appearance } \\
\text { competency }\end{array}$ & 5 months & $\begin{array}{l}\text { Differences 'not significant' between } \\
\text { children in the intervention and control } \\
\text { groups ( } P \text { value not reported) }\end{array}$ \\
\hline
\end{tabular}

\begin{tabular}{|c|c|c|c|c|c|}
\hline Lewis 1990 & $\mathrm{RCT}$ & $\begin{array}{l}\text { Children and } \\
\text { parents (CEP) }\end{array}$ & $\begin{array}{l}\text { Behaviour com- } \\
\text { petency }\end{array}$ & 5 months & $\begin{array}{l}\text { Differences 'not significant' between } \\
\text { children in the intervention and control } \\
\text { groups ( } \mathrm{P} \text { value not reported) }\end{array}$ \\
\hline
\end{tabular}

\begin{tabular}{|c|c|c|c|c|c|}
\hline Lewis 1990 & RCT & $\begin{array}{l}\text { Children and } \\
\text { parents (CEP) }\end{array}$ & $\begin{array}{l}\text { Self-esteem } \\
\text { competency }\end{array}$ & 5 months & $\begin{array}{l}\text { Differences 'not significant' between } \\
\text { children in the intervention and control } \\
\text { groups ( } \mathrm{P} \text { value not reported) }\end{array}$ \\
\hline
\end{tabular}

\begin{tabular}{|c|c|c|c|c|c|}
\hline Lewis 1990 & RCT & $\begin{array}{l}\text { Children and } \\
\text { parents (CEP) }\end{array}$ & $\begin{array}{l}\text { Gain in Social } \\
\text { skills }\end{array}$ & 5 months & $\begin{array}{l}\text { Children in the intervention group were } \\
\text { more likely to report gain in social skills } \\
\text { (mean: } 9 \% \text { with intervention versus } 2 \% \\
\text { with control; } P<0.02 \text { ) }\end{array}$ \\
\hline
\end{tabular}

\begin{tabular}{llll}
\hline Lewis 1990 & RCT & $\begin{array}{l}\text { Children and } \\
\text { parents (CEP) }\end{array}$ & $\begin{array}{l}\text { Participation in } \\
\text { normal activities }\end{array}$
\end{tabular}$\quad$\begin{tabular}{ll}
5 months & $\begin{array}{l}\text { Children in the intervention group were } \\
\text { more likely to report participation in nor- } \\
\text { mal activities (mean: } 11 \% \text { with interven- } \\
\text { tion versus 3.5\% with control; } P<0.03)\end{array}$ \\
\hline
\end{tabular}

\begin{tabular}{|c|c|c|c|c|c|}
\hline Lewis 1990 & $\mathrm{RCT}$ & $\begin{array}{l}\text { Children and } \\
\text { parents (CEP) }\end{array}$ & $\begin{array}{l}\text { Children's self- } \\
\text { care skills }\end{array}$ & 5 months & $\begin{array}{l}\text { Differences 'not significant' between } \\
\text { children in the intervention and control } \\
\text { groups ( } P \text { value not reported) }\end{array}$ \\
\hline Lewis 1990 & $\mathrm{RCT}$ & $\begin{array}{l}\text { Children and } \\
\text { parents (CEP) }\end{array}$ & $\begin{array}{l}\text { Children's re- } \\
\text { ports of parents' } \\
\text { behaviours }\end{array}$ & 5 months & $\begin{array}{l}\text { Differences 'not significant' between } \\
\text { children in the intervention and control } \\
\text { groups ( } P \text { value not reported) }\end{array}$ \\
\hline Lewis 1990 & $\mathrm{RCT}$ & $\begin{array}{l}\text { Children and } \\
\text { parents (CEP) }\end{array}$ & $\begin{array}{l}\text { Children's disclo- } \\
\text { sure of epileptic } \\
\text { status }\end{array}$ & 5 months & $\begin{array}{l}\text { Differences 'not significant' between } \\
\text { children in the intervention and control } \\
\text { groups ( } P \text { value not reported) }\end{array}$ \\
\hline Lewis 1991 & $\mathrm{RCT}$ & $\begin{array}{l}\text { Children and } \\
\text { parents (CEP) }\end{array}$ & $\begin{array}{l}\text { Parental anxiety } \\
\text { - Taylor Manifest } \\
\text { Anxiety Scale }\end{array}$ & 5 months & $\begin{array}{l}\text { Parents in the intervention group showed } \\
\text { greater reductions in anxiety than par- } \\
\text { ents in the control group }(P<0.01)\end{array}$ \\
\hline Lewis 1991 & $\mathrm{RCT}$ & $\begin{array}{l}\text { Children and } \\
\text { parents (CEP) }\end{array}$ & $\begin{array}{l}\text { Parental anxiety } \\
\text { - feeling less anx- } \\
\text { ious }\end{array}$ & 5 months & $\begin{array}{l}\text { Statistically significant difference in the } \\
\text { proportion of parents who reported feel- } \\
\text { ing less anxious and fearful after the ses- } \\
\text { sions (mean: } 31 \% \text { with intervention ver- } \\
\text { sus } 10 \% \text { with control; } P<0.001 \text { ) }\end{array}$ \\
\hline Pfäfflin 2012 & $\begin{array}{l}\text { Controlled be- } \\
\text { fore-and-after } \\
\text { study }\end{array}$ & $\begin{array}{l}\text { Children } \\
\text { and parents } \\
\text { (FAMOSES) }\end{array}$ & Quality of life & 3 months & $\begin{array}{l}\text { No statistically significant differences be- } \\
\text { tween children in the intervention and } \\
\text { control groups (reported in Rau 2006; P } \\
\text { value not reported) }\end{array}$ \\
\hline Pfäfflin 2012 & $\begin{array}{l}\text { Controlled be- } \\
\text { fore-and-after } \\
\text { study }\end{array}$ & $\begin{array}{l}\text { Children } \\
\text { and parents } \\
\text { (FAMOSES) }\end{array}$ & Quality of life & 3 months & $\begin{array}{l}\text { No statistically significant differences be- } \\
\text { tween children in the intervention and } \\
\text { control groups (reported in Rau 2006; P } \\
\text { value not reported) }\end{array}$ \\
\hline Pfäfflin 2012 & $\begin{array}{l}\text { Controlled be- } \\
\text { fore-and-after } \\
\text { study }\end{array}$ & $\begin{array}{l}\text { Children } \\
\text { and parents } \\
\text { (FAMOSES) }\end{array}$ & $\begin{array}{l}\text { Coping with } \\
\text { epilepsy }\end{array}$ & 3 months & $\begin{array}{l}\text { No statistically significant differences be- } \\
\text { tween children in the intervention and } \\
\text { control groups (reported in Rau 2006; P } \\
\text { value not reported) }\end{array}$ \\
\hline
\end{tabular}


Table 4. Health and quality of life (including side-effects of medication) (Continued)

\begin{tabular}{|c|c|c|c|c|c|}
\hline Pfäfflin 2012 & $\begin{array}{l}\text { Controlled be- } \\
\text { fore-and-after } \\
\text { study }\end{array}$ & $\begin{array}{l}\text { Children } \\
\text { and parents } \\
\text { (FAMOSES) }\end{array}$ & $\begin{array}{l}\text { Coping with } \\
\text { epilepsy }\end{array}$ & 3 months & $\begin{array}{l}\text { No statistically significant differences be- } \\
\text { tween parents in the intervention group } \\
\text { versus control ( } P \text { value not reported) }\end{array}$ \\
\hline Pfäfflin 2012 & $\begin{array}{l}\text { Controlled be- } \\
\text { fore-and-after } \\
\text { study }\end{array}$ & $\begin{array}{l}\text { Children } \\
\text { and parents } \\
\text { (FAMOSES) }\end{array}$ & $\begin{array}{l}\text { Adaption to } \\
\text { epilepsy* }\end{array}$ & 3 months & $\begin{array}{l}\text { Significantly improved amongst parents } \\
\text { in the intervention group versus control } \\
(P=0.001)\end{array}$ \\
\hline Pfäfflin 2012 & $\begin{array}{l}\text { Controlled be- } \\
\text { fore-and-after } \\
\text { study }\end{array}$ & $\begin{array}{l}\text { Children } \\
\text { and parents } \\
\text { (FAMOSES) }\end{array}$ & $\begin{array}{l}\text { Anxiety about } \\
\text { epilepsy }\end{array}$ & 3 months & $\begin{array}{l}\text { No statistically significant differences be- } \\
\text { tween children in the intervention and } \\
\text { control groups (reported in Rau 2006; P } \\
\text { value not reported) }\end{array}$ \\
\hline Pfäfflin 2012 & $\begin{array}{l}\text { Controlled be- } \\
\text { fore-and-after } \\
\text { study }\end{array}$ & $\begin{array}{l}\text { Children } \\
\text { and parents } \\
\text { (FAMOSES) }\end{array}$ & $\begin{array}{l}\text { Anxiety about } \\
\text { epilepsy }\end{array}$ & 3 months & $\begin{array}{l}\text { Significantly improved amongst parents } \\
\text { in the intervention group versus control } \\
(P=0.014)\end{array}$ \\
\hline Pfäfflin 2012 & $\begin{array}{l}\text { Controlled be- } \\
\text { fore-and-after } \\
\text { study }\end{array}$ & $\begin{array}{l}\text { Children } \\
\text { and parents } \\
\text { (FAMOSES) }\end{array}$ & $\begin{array}{l}\text { Rules and limita- } \\
\text { tions: social re- } \\
\text { strictions (a child } \\
\text { with epilepsy } \\
\text { should not sleep } \\
\text { overnight with } \\
\text { classmates) }\end{array}$ & 3 months & $\begin{array}{l}\text { Reduced social limitations amongst chil- } \\
\text { dren in the intervention group versus } \\
\text { control ( } P=0.017 \text {; reported in Rau 2006) }\end{array}$ \\
\hline Pfäfflin 2012 & $\begin{array}{l}\text { Controlled be- } \\
\text { fore-and-after } \\
\text { study }\end{array}$ & $\begin{array}{l}\text { Children } \\
\text { and parents } \\
\text { (FAMOSES) }\end{array}$ & $\begin{array}{l}\text { Rules and limita- } \\
\text { tions: social re- } \\
\text { strictions (a child } \\
\text { with epilepsy } \\
\text { should not sleep } \\
\text { overnight with } \\
\text { classmates) }\end{array}$ & 3 months & $\begin{array}{l}\text { No statistically significant differences be- } \\
\text { tween parents in the intervention group } \\
\text { versus control }(P=0.081)\end{array}$ \\
\hline Pfäfflin 2012 & $\begin{array}{l}\text { Controlled be- } \\
\text { fore-and-after } \\
\text { study }\end{array}$ & $\begin{array}{l}\text { Children } \\
\text { and parents } \\
\text { (FAMOSES) }\end{array}$ & $\begin{array}{l}\text { Rules and limita- } \\
\text { tions: sporting } \\
\text { restrictions (a } \\
\text { child with epilep- } \\
\text { sy should not at- } \\
\text { tend sports at } \\
\text { school because } \\
\text { of high risk of in- } \\
\text { juries) }\end{array}$ & 3 months & $\begin{array}{l}\text { No statistically significant differences be- } \\
\text { tween children in the intervention and } \\
\text { control groups (reported in Rau 2006; P } \\
\text { value not reported) }\end{array}$ \\
\hline Pfäfflin 2012 & $\begin{array}{l}\text { Controlled be- } \\
\text { fore-and-after } \\
\text { study }\end{array}$ & $\begin{array}{l}\text { Children } \\
\text { and parents } \\
\text { (FAMOSES) }\end{array}$ & $\begin{array}{l}\text { Rules and lim- } \\
\text { itations: atten- } \\
\text { dance restric- } \\
\text { tions (a school } \\
\text { aged child with } \\
\text { epilepsy should } \\
\text { not sleep in a } \\
\text { separate room) }\end{array}$ & 3 months & $\begin{array}{l}\text { No statistically significant differences be- } \\
\text { tween children in the intervention and } \\
\text { control groups (reported in Rau 2006; P } \\
\text { value not reported) }\end{array}$ \\
\hline Pfäfflin 2012 & $\begin{array}{l}\text { Controlled be- } \\
\text { fore-and-after } \\
\text { study }\end{array}$ & $\begin{array}{l}\text { Children } \\
\text { and parents } \\
\text { (FAMOSES) }\end{array}$ & $\begin{array}{l}\text { Rules and lim- } \\
\text { itations: atten- } \\
\text { dance restric- } \\
\text { tions (a school } \\
\text { aged child with } \\
\text { epilepsy should }\end{array}$ & 3 months & $\begin{array}{l}\text { Significantly improved amongst parents } \\
\text { in the intervention group versus control } \\
(P=0.031)\end{array}$ \\
\hline
\end{tabular}


Table 4. Health and quality of life (including side-effects of medication) (Continued)

not sleep in a

separate room)*

\begin{tabular}{|c|c|c|c|c|c|}
\hline Pfäfflin 2012 & $\begin{array}{l}\text { Controlled be- } \\
\text { fore-and-after } \\
\text { study }\end{array}$ & $\begin{array}{l}\text { Children } \\
\text { and parents } \\
\text { (FAMOSES) }\end{array}$ & $\begin{array}{l}\text { Attitudes to- } \\
\text { wards epilepsy }\end{array}$ & 3 months & $\begin{array}{l}\text { No statistically significant differences be- } \\
\text { tween children in the intervention and } \\
\text { control groups (reported in Rau 2006; P } \\
\text { value not reported) }\end{array}$ \\
\hline Pfäfflin 2012 & $\begin{array}{l}\text { Controlled be- } \\
\text { fore-and-after } \\
\text { study }\end{array}$ & $\begin{array}{l}\text { Children } \\
\text { and parents } \\
\text { (FAMOSES) }\end{array}$ & $\begin{array}{l}\text { Impact of epilep- } \\
\text { sy^ }\end{array}$ & 3 months & $\begin{array}{l}\text { No statistically significant differences be- } \\
\text { tween parents in the intervention group } \\
\text { versus control ( } P \text { value not reported) }\end{array}$ \\
\hline $\begin{array}{l}\text { Tieffenberg } \\
2000\end{array}$ & $\mathrm{RCT}$ & $\begin{array}{l}\text { Children and } \\
\text { parents (ACIN- } \\
\text { DES) }\end{array}$ & $\begin{array}{l}\text { Allowed child to } \\
\text { sleep at friends' } \\
\text { homes more of- } \\
\text { ten }\end{array}$ & 12 months & $\begin{array}{l}\text { After participating in the groups, the par- } \\
\text { ents of children with epilepsy allowed } \\
\text { them to sleep at friends' homes more of- } \\
\text { ten (probability of gain }=0.59 \text {, variance = } \\
0.0026 \text { ) }\end{array}$ \\
\hline
\end{tabular}

*Not reported for children Rau 2006

Table 5. Objective measures of social or psychological functioning (including the number of days spent on sick leave/absence from school and employment status)

\begin{tabular}{|c|c|c|c|c|c|}
\hline Study & Study type & $\begin{array}{l}\text { Strategy de- } \\
\text { signed for }\end{array}$ & Outcome & $\begin{array}{l}\text { Outcome } \\
\text { time }\end{array}$ & Findings \\
\hline $\begin{array}{l}\text { Glueckauf } \\
2002\end{array}$ & $\begin{array}{l}\text { RCT (but with } \\
\text { failed ran- } \\
\text { domisation) }\end{array}$ & $\begin{array}{l}\text { Teenagers and } \\
\text { parents }\end{array}$ & $\begin{array}{l}\text { Adherence to } \\
\text { the treatment } \\
\text { programme } \\
\text { (number of } \\
\text { missed ap- } \\
\text { pointments) }\end{array}$ & 6 months & $\begin{array}{l}\text { No statistically significant differences be- } \\
\text { tween the intervention and control groups } \\
\text { (P value not reported) }\end{array}$ \\
\hline $\begin{array}{l}\text { Glueckauf } \\
2002\end{array}$ & $\begin{array}{l}\text { RCT (but with } \\
\text { failed ran- } \\
\text { domisation) }\end{array}$ & $\begin{array}{l}\text { Teenagers and } \\
\text { parents }\end{array}$ & $\begin{array}{l}\text { Adherence to } \\
\text { the treatment } \\
\text { programme } \\
\text { (extent of the } \\
\text { homework } \\
\text { completion) }\end{array}$ & 6 months & $\begin{array}{l}\text { No statistically significant differences be- } \\
\text { tween the intervention and control groups } \\
\text { (P value not reported) }\end{array}$ \\
\hline Modi 2016 & $\mathrm{RCT}$ & $\begin{array}{l}\text { Children } \\
\text { and parents } \\
\text { (STAR) }\end{array}$ & $\begin{array}{l}\text { Social prob- } \\
\text { lem-solving }\end{array}$ & 3 months & $\begin{array}{l}\text { No statistically significant differences be- } \\
\text { tween the intervention and control groups } \\
\text { ( } P \text { value not reported) }\end{array}$ \\
\hline Modi 2016 & $\mathrm{RCT}$ & $\begin{array}{l}\text { Children } \\
\text { and parents } \\
\text { (STAR) }\end{array}$ & $\begin{array}{l}\text { Parents' self- } \\
\text { management }\end{array}$ & 3 months & $\begin{array}{l}\text { Statistically significant improved between } \\
\text { groups in favour of the intervention group }(P \\
<0.05)\end{array}$ \\
\hline Modi 2016 & $\mathrm{RCT}$ & $\begin{array}{l}\text { Children } \\
\text { and parents } \\
\text { (STAR) }\end{array}$ & $\begin{array}{l}\text { Parents' re- } \\
\text { sponse to } \\
\text { child illness }\end{array}$ & 3 months & $\begin{array}{l}\text { No statistically significant differences be- } \\
\text { tween the intervention and control groups } \\
\text { (P value not reported) }\end{array}$ \\
\hline Pfäfflin 2012 & $\begin{array}{l}\text { Controlled be- } \\
\text { fore-and-after } \\
\text { study }\end{array}$ & $\begin{array}{l}\text { Children } \\
\text { and parents } \\
\text { (FAMOSES) }\end{array}$ & $\begin{array}{l}\text { School ab- } \\
\text { senteeism } \\
\text { (days missed } \\
\text { at school) }\end{array}$ & 3 months & $\begin{array}{l}\text { No statistically significant differences be- } \\
\text { tween children in the intervention and con- } \\
\text { trol groups (reported in Rau 2006; P value } \\
\text { not reported) }\end{array}$ \\
\hline
\end{tabular}


Table 5. Objective measures of social or psychological functioning (including the number of days spent on sick leave/absence from school and employment status) (Continued)

\begin{tabular}{|c|c|c|c|}
\hline $\begin{array}{l}\text { Tieffenberg } \\
2000\end{array}$ & RCT & $\begin{array}{l}\text { Children and } \\
\text { parents (ACIN- } \\
\text { DES) }\end{array}$ & $\begin{array}{l}\text { Emergency } \\
\text { visits }\end{array}$ \\
\hline
\end{tabular}
Significantly fewer emergency visits in chil- dren who received the intervention com- pared to control (mean at baseline to 12 months: 0.90 visits (SD 0.95) to 0.22 visits (SD 0.58) with intervention versus 0.83 visits (SD 0.95) to 0.46 visits (SD 0.66) with control; $P=0.046)$

\begin{tabular}{|c|c|c|c|c|c|}
\hline $\begin{array}{l}\text { Tieffenberg } \\
2000\end{array}$ & RCT & $\begin{array}{l}\text { Children and } \\
\text { parents (ACIN- } \\
\text { DES) }\end{array}$ & $\begin{array}{l}\text { Regular med- } \\
\text { ical visits }\end{array}$ & 12 months & $\begin{array}{l}\text { No statistically significant differences in chil- } \\
\text { dren who received the intervention com- } \\
\text { pared to control ( } P \text { value not reported) }\end{array}$ \\
\hline $\begin{array}{l}\text { Tieffenberg } \\
2000\end{array}$ & RCT & $\begin{array}{l}\text { Children and } \\
\text { parents (ACIN- } \\
\text { DES) }\end{array}$ & $\begin{array}{l}\text { School absen- } \\
\text { teeism }\end{array}$ & 12 months & $\begin{array}{l}\text { Statistically significant improvement in } \\
\text { children who received the intervention } \\
\text { compared to control (mean number of ab- } \\
\text { sences per } 100 \text { school days at baseline to } 12 \\
\text { months: } 10.31 \text { to } 6.85 \text { absences with inter- } \\
\text { vention versus } 9.32 \text { to } 9.21 \text { absences with } \\
\text { control; } P=0.011 \text { ) }\end{array}$ \\
\hline
\end{tabular}

\section{AP PEN DICES}

\section{Appendix 1. Cochrane Epilepsy Group Specialized Register search strategy}

Previous review update (searches conducted: 9 December 2013)

\#1 MeSH DESCRIPTOR Program Evaluation Explode All WITH EC MT ST SN TD

\#2 MeSH DESCRIPTOR Delivery of Health Care Explode All WITH CL EC ES EH HI LJ MA MT OG ST SN TD UT

\#3 MeSH DESCRIPTOR Ambulatory Care Explode All WITH CL EC ES HI LJ MA MT OG PX ST SN TD UT

\#4 MeSH DESCRIPTOR Outcome and Process Assessment (Health Care) Explode All WITH CL EC ES HI LJ MT OG ST SN TD UT

\#5 epilep* NEAR4 (centre* OR center ${ }^{\star}$ )

\#6 epilep* NEAR3 specialist*

\#7 epilep* NEAR2 nurs*

\#8 \#1 OR \#2 OR \#3 OR \#4 OR \#5 OR \#6 OR \#7

\#9 \#8 AND INREGISTER AND >2011:YR

\section{This review update (searches conducted: 27 September 2016)}

\#1 MeSH DESCRIPTOR Program Evaluation Explode All

\#2 MeSH DESCRIPTOR Delivery of Health Care Explode All

\#3 MeSH DESCRIPTOR Ambulatory Care Explode All

\#4 MeSH DESCRIPTOR Outcome and Process Assessment (Health Care) Explode All

\#5 program* NEAR2 evaluat*

\#6 epilep* NEAR3 specialist*

\#7 epilep* NEAR2 nurs*

\#8 \#1 OR \#2 OR \#3 OR \#4 OR \#5 OR \#6 OR \#7

\#9 \#8 AND >2011:YR

\section{Appendix 2. Cochrane Central Register of Controlled Trials (CENTRAL) search strategy}

Previous review update (searches conducted: 9 December 2013)

\#1 MeSH descriptor: [Epilepsy] explode all trees

\#2 epilep*

\#3 (\#1 or \#2)

\#4 MeSH descriptor: [Program Evaluation] explode all trees

\#5 MeSH descriptor: [Delivery of Health Care] explode all trees

\#6 (\#4 or \#5) 
$\# 7$ (\#3 and \#6)

\#8 MeSH descriptor: [Ambulatory Care] explode all trees

\#9 (\#3 and \#8)

\#10 epilep* near/4 centre*:ti,ab,kw (Word variations have been searched)

\#11 epilep* near/4 center*:ti,ab,kw (Word variations have been searched)

\#12 epilep* near/3 specialist*:ti,ab,kw (Word variations have been searched)

\#13 epilep* near/2 nurs*:ti,ab,kw (Word variations have been searched)

\#14 MeSH descriptor: [Outcome and Process Assessment (Health Care)] explode all trees

$\# 15$ (\#14 and \#3)

$\# 16$ (\#7 or \#9 or \#10 or \#11 or \#12 or \#13 or \#15) from 2012, in Trials

This review update (searches conducted: 27 September 2016)

\#1 MESH DESCRIPTOR Epilepsy EXPLODE ALL TREES

\#2 epilep*:TI,AB,KY

\#3 \#1 OR \#2

\#4 MESH DESCRIPTOR Program Evaluation EXPLODE ALL TREES

\#5 MESH DESCRIPTOR Delivery of Health Care EXPLODE ALL TREES

\#6 MESH DESCRIPTOR Ambulatory Care EXPLODE ALL TREES

\#7 MESH DESCRIPTOR Outcome and Process Assessment (Health Care) EXPLODE ALL TREES

\#8 (program ${ }^{\star}$ NEAR2 evaluat $\left.{ }^{\star}\right): T 1, A B, K Y$

\#9 \#4 OR \#5 OR \#6 OR \#7 OR \#8

\#10 \#3 AND \#9

\#11 (epilep* NEAR3 specialist $\left.{ }^{\star}\right): T I, A B, K Y$

\#12 (epilep* NEAR2 nurs $\left.{ }^{\star}\right): T I, A B, K Y$

\#13 \#10 OR \#11 OR \#12

\#14 30/11/2013 TO 31/10/2016:DL

\#15 \#13 AND \#14

\#16 ("Conference Abstract"):PT AND INEMBASE

\#17 \#15 NOT \#16

\section{Appendix 3. MEDLINE search strategy}

\section{Original review}

\#1 exp EPILEPSY/

\#2 epilep\$.tw.

\#3 1 or 2

\#4 exp Program Evaluation/

\#5 exp "Delivery of Health Care"/

\#6 4 or 5

$\# 73$ and 6

\#8 exp Ambulatory Care/

\#9 3 and 8

\#10 (epilep\$ adj4 centre\$).ab,ti.

\#11 (epilep\$ adj4 center\$).ab,ti.

\#12 (epilep\$ adj3 specialist\$).ab,ti.

\#13 (epilep\$ adj2 nurs\$).ab,ti.

\#14 exp "Outcome Assessment (Health Care)"/

\#15 14 and 3

\#16 7 or 9 or 10 or 11 or 12 or 13 or 15

\section{Previous review update (searches conducted: 24 June 2012)}

\#1 exp Epilepsy/

\#2 epilep\$.mp.

\#3 1 or 2

\#4 exp Program Evaluation/

\#5 exp "Delivery of Health Care"/

\#6 exp Ambulatory Care/

$\# 7$ *"Outcome Assessment (Health Care)"/

\#8 (program\$ adj2 evaluat\$).mp.

\#9 4 or 5 or 6 or 7 or 8

$\# 103$ and 9 
\#11 (epilep\$ adj4 (centre\$ or center\$)).mp.

\#12 (epilep\$ adj3 nurs\$).mp.

\#13 (epilep\$ adj3 specialist\$).mp.

\#14 11 or 12 or 13

$\# 1510$ and 14

\#16 limit 15 to yr="2012 -Current"

\section{This review update (searches conducted: 27 September 2016)}

\#1 exp Epilepsy/

\#2 epilep\$.tw.

\#3 1 or 2

\#4 exp Program Evaluation/

\#5 exp "Delivery of Health Care"/

\#6 exp Ambulatory Care/

\#7 *"Outcome Assessment (Health Care)"/

\#8 (program\$ adj2 evaluat\$).tw.

\#9 4 or 5 or 6 or 7 or 8

$\# 103$ and 9

\#11 (epilep\$ adj3 nurs\$).tw.

\#12 (epilep\$ adj3 specialist\$).tw.

$\# 1311$ or 12

\#14 10 or 13

\#15 (randomized controlled trial or controlled clinical trial).pt. or (randomi?ed or placebo or randomly).ab.

\#16 clinical trials as topic.sh.

\#17 trial.ti.

\#18 15 or 16 or 17

\#19 (clinical trial or clinical trial phase i or clinical trial phase ii or clinical trial phase iii or clinical trial phase iv or comparative study or evaluation studies or multicenter study or observational study or pragmatic clinical trial or validation studies).pt.

\#20 ((clinical or comparative or evaluation or multicenter or multi-center or multicentre or multi-centre or validation) adj2 (study or studies or trial?)).tw,hw.

\#21 epidemiologic studies/or exp case-control studies/or exp cohort studies/or exp controlled before-after studies/or exp cross-sectional studies/ or exp historically controlled study/ or exp interrupted time series analysis/

\#22 (cohort\$ or (case\$ adj2 control\$) or (case\$ adj2 series)).tw,hw.

\#23 epidemiologic methods/

\#24 limit 23 to $y r=1966-1989$

\#25 (("before and after" or "before-and-after" or case\$ or cross?section\$ or "cross section\$" or "follow up" or "follow-up" or longitudinal or observation\$ or prospective or "record-linkage" or "record linkage" or retrospective or "time-series" or "time series") adj2 (analy\$ or method or procedure or study or studies or trial?)).tw,hw.

\#26 ("quasi-experiment\$" or quasiexperiment\$ or "quasi experiment\$" or "quasi random\$" or "quasi-random\$" or quasirandom\$ or "quasi control\$" or "quasi-control\$" or quasicontrol\$).ti,ab,hw.

\#27 (time points adj3 (over or multiple or three or four or five or six or seven or eight or nine or ten or eleven or twelve or month\$ or hour? or day? or "more than")).ab.

\#28 (control adj3 (area or cohort? or compare? or condition or design or group? or intervention? or participant? or study)).ab. not (controlled clinical trial or randomized controlled trial).pt.

\#29 (control year? or experimental year? or control period? or experimental period?).ti,ab.

\#30 ((strategy or strategies) adj2 (improv\$ or education\$)).ti,ab.

\#31 19 or 20 or 21 or 22 or 24 or 25 or 26 or 27 or 28 or 29 or 30

\#32 18 or 31

\#33 exp animals/ not humans.sh.

\#34 32 not 33

\#35 34 not case reports.pt.

\#36 14 and 35

\#37 remove duplicates from 36

\#38 limit 37 to ed=20120701-20160927

\section{Appendix 4. Embase search strategy}

\section{Original review}

\#1 exp Epilepsy/

$\# 2$ epilep\$

\#3 1 or 2

Care delivery and self-management strategies for children with epilepsy (Review) 
\#4 exp Ambulatory Care/ \#5 exp Institutional Care/ \#6 exp Community Care/ \#7 exp Health Care Delivery/ \#8 *Outcomes Research/ \#9 (program\$ adj2 evaluat\$) \#10 4 or 5 or 6 or 7 or 8 or 9

$\# 113$ and 10

\#12 (center\$ or centre\$)

\#13 nurs\$

\#14 specialist\$

\#15 (epilep\$ adj4 (centre\$ or center\$))

\#16 (epilep\$ adj3 nurs\$)

\#17 (epilep\$ adj3 specialist\$)

\#18 11 or 15 or 16 or 17

\section{Previous review update (searches conducted: 24 June 2012)}

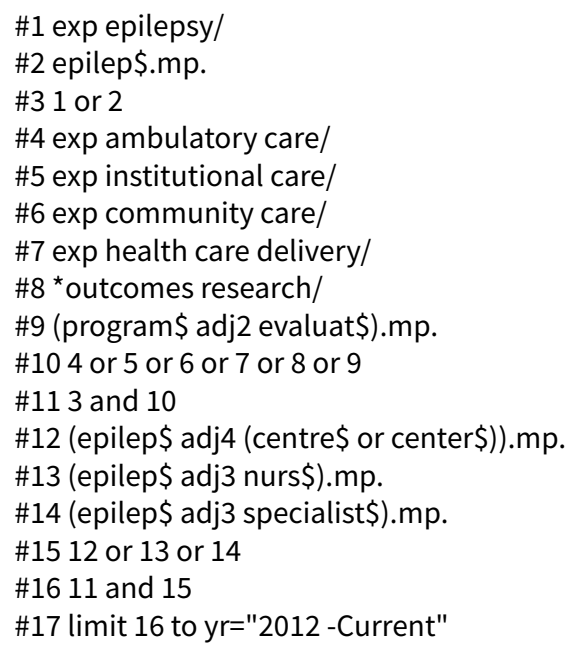

This review update (searches conducted: 1 November 2016)

\#1 exp epilepsy/

\#2 epilep\$.mp.

\#3 1 or 2

\#4 exp ambulatory care/

\#5 exp institutional care/

\#6 exp community care/

\#7 exp health care delivery/

\#8 *outcomes research/

\#9 (program\$ adj2 evaluat\$).mp.

\#10 4 or 5 or 6 or 7 or 8 or 9

$\# 113$ and 10

\#12 (epilep\$ adj4 (centre\$ or center\$)).mp.

\#13 (epilep\$ adj3 nurs\$).mp.

\#14 (epilep\$ adj3 specialist\$).mp.

$\# 1512$ or 13 or 14

\#16 11 and 15

\#17 limit 16 to yr="2012 -Current"

\section{Appendix 5. PsycINFO search strategy}

\section{Original review}

This search was carried out in two phases. The first search was carried out in May 2006 using the following strategy: $\# 10 \# 1$ and \#9

\#9 \#2 or \#3 or \#4 or \#5 or \#6 or \#7 or \#8

\#8 specialist $^{\star}$ 
\#7 nurs*

\#6 centre* or center*

\#5 treatment effectiveness evaluation

\#4 treatment outcome*

\#3 health care delivery

$\# 2$ ambulatory care

\#1 epilep*

The second search was carried out in March 2010 using the EBSCO host platform for PsycINFO, and the following strategy:

$\mathrm{S} 12 \mathrm{~S} 8$ or $\mathrm{S} 9$ or $\mathrm{S} 10$ or $\mathrm{S} 11$

S11 S3 and S7

S10 epilep* N3 specialist*

S9 epilep* N3 nurs*

S8 epilep* N4 center ${ }^{\star}$ or epilep* N4 centre*

S7 S4 or S5 or S6

S6 MM "Program Evaluation"

S5 MM "Health Care Delivery"

S4 MM "Outpatient Treatment"

S3 S1 or S2

S2 epilep*

S1 MM “Epilepsy” or DE “Epileptic Seizures” or DE "Grand Mal Seizures” or DE "Petit Mal Seizures”

\section{Previous review update (searches conducted: 11 December 2012)}

S12 S8 OR S9 OR S10 OR S11

Limiters - Publication Year: 2012-

S11 S3 AND S7

S10 TI epilep* N3 specialist* OR AB epilep* N3 specialist* OR SU epilep* N3 specialist*

S9 TI epilep* N3 nurs* OR AB epilep* N3 nurs* OR SU epilep* N3 nurs*

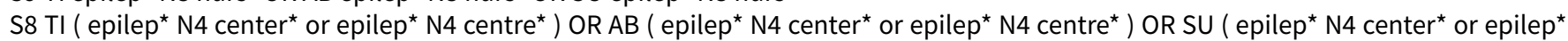
N4 centre* )

S7 S4 OR S5 OR S6

S6 MM "Program Evaluation"

S5 MM "Health Care Delivery"

S4 MM "Outpatient Treatment"

S3 S1 OR S2

S2 epilep*

S1 MM "Epilepsy" OR DE "Epileptic Seizures" OR DE "Grand Mal Seizures" OR DE "Petit Mal Seizures"

This review update (searches conducted: 27 September 2016)

S12 S9 OR S10 OR S11

Publication Year: 2012-

S11 TI epilep* N3 specialist* OR AB epilep* N3 specialist* OR SU epilep* N3 specialist*

S10 TI epilep* N3 nurs* OR AB epilep* N3 nurs* OR SU epilep* N3 nurs*

S9 S3 AND S8

S8 S4 OR S5 OR S6 OR S7

S7 TI program * N2 evaluat ${ }^{\star}$ OR AB program* N2 evaluat* OR SU program* N2 evaluat ${ }^{\star}$

S6 MM "Program Evaluation"

S5 MM "Health Care Delivery"

S4 MM "Outpatient Treatment"

S3 S1 OR S2

S2 epilep*

S1 MM "Epilepsy" OR DE "Epileptic Seizures" OR DE "Grand Mal Seizures" OR DE "Petit Mal Seizures"

\section{Appendix 6. CINAHL search strategy}

\section{Original review}

This search was carried out in two phases. The first search was carried out in May 2006 using the Ovid platform for CINAHL, and the following strategy:

\#1 exp EPILEPSY/

\#2 epilep\$.tw. 
\#3 1 or 2

\#4 exp Ambulatory Care/

\#5 exp Health Care Delivery/

\#6 exp Program Evaluation/

\#7 exp "Outcomes (Health Care)"/

\#8 (epilep\$ adj4 (centre\$ or center\$)).tw.

\#9 (epilep\$ adj3 nurs\$).tw.

\#10 (epilep\$ adj3 specialist\$).tw.

$\# 114$ or 5 or 6 or 7

\#12 3 and 11

\#13 8 or 9 or 10 or 12

The second search was carried out in March 2010 using the EBSCO host platform for CINAHL, and the following strategy:

$\mathrm{S} 13 \mathrm{~S} 9$ or $\mathrm{S} 10$ or $\mathrm{S} 11$ or $\mathrm{S} 12$

S12 S3 and S8

S11 epilep* N3 specialist*

S10 epilep* N3 nurs*

S9 epilep* N4 centre* or epilep* N4 center*

S8 S4 or S5 or S6 or S7

S7 (MM "Outcomes (Health Care)")

S6 (MM "Program Evaluation")

S5 (MM "Health Care Delivery")

S4 (MM "Ambulatory Care")

S3 S1 or S2

S2 epilep*

S1 (MH "Epilepsy+")

\section{Previous review update (searches conducted: 11 December 2012)}

S13 S9 OR S10 OR S11 OR S12

Limiters - Published: 20120101-

S12 S3 AND S8

S11 epilep* N3 specialist*

S10 epilep* N3 nurs*

S9 (epilep* N4 centre*) or (epilep* N4 center ${ }^{\star}$ )

S8 S4 OR S5 OR S6 OR S7

S7 (MM "Outcomes (Health Care)")

S6 (MM "Program Evaluation")

S5 (MM "Health Care Delivery")

S4 (MM "Ambulatory care")

S3 S1 OR S2

S2 epilep*

S1 (MH "Epilepsy+")

This review update (searches conducted: 27 September 2016)

S13 S10 OR S11 OR S12

Published: 20120101-

S12 epilep* N3 specialist *

S11 epilep* N3 nurs $^{\star}$

S10 S3 AND S9

S9 S4 OR S5 OR S6 OR S7 OR S8

S8 program* $\mathrm{N} 2$ evaluat*

S7 (MM "Outcomes (Health Care)")

S6 (MM "Program Evaluation")

S5 (MM "Health Care Delivery")

S4 (MM "Ambulatory Care")

S3 S1 OR S2

S2 epilep*

S1 (MH "Epilepsy+") 


\section{Appendix 7. ClinicalTrials.gov search strategy}

This review update (searches conducted: 27 September 2016)

(Care delivery OR Care management) AND epilepsy

\section{Appendix 8. World Health Organization International Clinical Trials Registry Platform search strategy}

This review update (searches conducted: 27 September 2016)

Care AND epilepsy NOT NCT*

\section{Appendix 9. Additional detail about the interventions evaluated}

\section{Strategies for children and parents}

\section{ACINDES}

ACINDES is a child-centred training model based on play techniques designed to be applied in institutions such as schools or community centres for children with moderate to severe conditions (asthma and epilepsy in Tieffenberg 2000). Group activities of the model include games, drawings, stories, videos, and roleplay.

The model is based on the idea of children's autonomy in which children are trained to assume a leading role in the management of their own health. The programme aims to provide children with self-management skills and help them to achieve self-reliance and to use appropriate preventive strategies, thereby improving their social functioning and quality of life. ACINDES also aims to enable parents to learn to recognise and accept their children's autonomy and become 'facilitators' rather than 'managers' in their child's self-management of their condition.

Teachers coordinate group activities which are supervised by programme physicians. These teachers are required to be trained in promoting children's self-regulation or autonomy as well as certain specific aspects of chronic conditions (asthma, epilepsy) and their clinical management. Groups of children are arranged according to age (6-8 years, 9-12 years, 13-15 years) with no more than 10 children per teacher. Parent groups are co-ordinated by one or two teachers but are not arranged according to the ages of the children. The child's physician participates in ACINDES by being invited to sessions, at which he or she meets separately with children and parents and answers their questions.

The programme consists of five weekly two-hour meetings, followed by a reinforcement meeting two to six months later. The aims of the sessions are to enable children and parents to:

- learn about the child's condition (asthma, epilepsy) and identify body signals and early warning signs;

- recognise the elements of equilibrium (maintaining balance, avoiding imbalance) and identify their own triggers;

- understand treatment, therapeutic alternatives and the usefulness of a direct patient-physician relationship;

- handle specific risk situations (identify risks and learn strategies to handle them, including emergency home treatments;

- develop appropriate decision-making strategies based on the child's own expected values.

\section{Children's Epilepsy Programme (CEP)}

The CEP was initially developed and piloted with 40 children with epilepsy (aged 7-12 years) at the Medical Center of the University of California in Los Angeles (UCLA) (Lewis 1990; Lewis 1991). It consists of 4 sessions, each lasting 1.5 hours and delivered at weekly intervals. Children and parents are taught separately, meeting to share experiences at the end of each session.

Each session has a specific theme.

- Session 1, understanding body messages: this uses electronic toys and cartoon drawings to teach children about seizures and to help them identify seizure-related emotions and feelings.

- Session 2, controlling seizures with medication: this focuses on seizure-related information, using a card-sorting exercise to separate facts and fictions about seizures. It also teaches seizure management and decision-making skills.

- Session 3, telling others in a matter-of-fact way: children are encouraged to share personal experiences, especially experiences with friends or peers, whether related to epilepsy or not. Children learn how to tell others about their epilepsy.

- Session 4, coping and adapting to balance my life: various exercises are used to develop coping skills, including ways of dealing with bullying or taunting or with negative attitudes.

The parental group of the CEP follows the same basic structure as the child-focused group but is based on a Rogerian model of counselling and enables parents to review the children's sessions as described above. The parental sessions for the intervention group are as follows (the paper does not report on who delivers these sessions). 
- Session 1, telling a story: parents introduce themselves to other group members and share their experiences of their child with epilepsy. A card-sorting exercise to dispel false perceptions or myths is undertaken.

- Session 2, making decisions: a decision-making process is used to develop decision-making skills.

- Session 3, working as a family system: the group develops their understanding of how a child's epilepsy can impact on family life and discuss their parenting styles;

- Session 4, coping and adapting: in this final session parents discuss how to be more open about their child's epilepsy and how to acknowledge the pain and grief that may arise when parenting a child with a chronic condition.

\section{FAMOSES}

While the content of the sessions for parents and children is similar, focusing on topics such as basic knowledge, diagnosis, treatment and living with epilepsy, each group is taught separately (Pfäfflin 2012; Rau 2006). FAMOSES was developed by a multidisciplinary group of neuropaediatricians, psychologists, social workers and educators. It was designed to be used in different settings (e.g. epilepsy centres, outpatient clinics, inpatient settings and in weekly or weekend courses). The number of participants is restricted to 6 in the children's programme and 12 in the parent's programme, with two trainers working with each group. Trainers are physicians, psychologists, social workers, therapeutic educators or electroencephalogram assistants. The co-operation of a physician and a psychologist as co-trainers in the parents' programme is reported to be very useful in covering the medical and emotional aspects (FAMOSES Project Group 2007). The programme was first implemented in Germany and Switzerland in the spring of 2005 and is now reported to be operating in different epilepsy centres in German-speaking countries. Using educational material such as age-related illustrations interrupted by games, the children's content is presented as a virtual journey by sea, in which a virtual crew of 'sailors' are accompanied by educated trainers. The virtual journey consists of 7 modules (60-90 minutes each).

- Harbour: group members become acquainted with each other and are motivated to discuss actively their experiences of epilepsy with each other.

- Rock Island: alongside information about the frequency of epilepsy, the influence of the disease on everyday activities and how to react in case of a seizure, children are encouraged to talk about emotions connected with epilepsy and how to deal with them.

- Volcano Island: the pathophysiological background of epilepsy is explained (i.e. causes, types of seizures and what happens in the brain during a seizure).

- Treasure Island: information about important diagnostic tests presented alongside an exploration of children's own experience and feelings with their seizures. Emphasis is placed on the importance of accurate observation and description of seizures.

- Fungus Rock: major aspects of therapy are explored including the aims of medical treatment, the need for active co-operation and therapeutic options if drugs do not work. Focus is given to individual therapeutic aims and children's own impact on managing the seizures and their consequences.

- Holiday Island: children are taught how to talk about epilepsy and how to react properly in the case of an observed seizure.

- Lighthouse Island: the content of the whole course is summarised and in a short ceremony, 'sailors' are promoted to 'captains' of their own ships. This is considered to be one step in managing their own lives with epilepsy.

The adult's content consists of 6 modules (60 to 90 minutes each).

- Module 1, overview: group members become acquainted with each other and are motivated to reflect actively on their own ideas and emotions about epilepsy.

- Module 2, basic knowledge: information is given about the causes or pathophysiology of epilepsy, as well as about different seizure types.

- Module 3, diagnostic: the role of diagnostic tests in the diagnosis and therapy of epilepsy are explained. The importance of seizure observation, description and documentation, and the need to support children in sensing and describing their own seizures is emphasised.

- Module 4, therapy: major aspects of epilepsy therapy are discussed. Medical treatment is the focal point but additional non-medical treatment options are also discussed. Materials to be explored at home are provided.

- Module 5, prognosis: the prognosis of different epilepsies with respect to seizure remission and discontinuation of antiepileptic drugs is explored alongside the motor and cognitive development of the child with epilepsy.

- Module 6, living with epilepsy: recognition of, and strategies for, coping with epilepsy-related emotional aspects of relationships with parents and siblings are explored. Group members have the opportunity to share their experiences, taking other participants as models to learn from and to be motivated by. Different disease management strategies are discussed, and hints are given on where to get help in critical situations (legal, financial, self-help, written and audio-visual information).

\section{Supporting Treatment Adherence Regimen (STAR)}

This family-tailored antiepileptic drug adherence intervention was developed by two paediatric psychologists specialising in epilepsy (Modi 2016). It consisted of four educational and problem-solving sessions over two months. In particular, the first session of the intervention focused on addressing deficits in epilepsy knowledge and providing education about the importance of antiepileptic drug adherence. This included: 
- education of epilepsy treatment and antiepileptic drug adherence;

- review of patient's prescribed treatment regimen;

- review of Epilepsy Knowledge Questionnaire.

The goals of the problem-solving approach were introduced during the second session and were as follows.

- Problem definition: family identified an important adherence barrier.

- Generating alternative solutions: family taught to generate several creative solutions.

- Family decision-making: family writes down solutions and systematically evaluate.

- Implementation of new solution: family selects one solution to implement (action plan).

- Evaluation and renegotiation: a detailed solution was written out with specifics regarding when, where, and how the new solution will be attempted, and a behavioural contract was signed by all participants of the problem-solving session; telephone follow-ups were conducted one week after the problem-solving session to assist the family in either fine-tuning the solution or renegotiating a new solution.

A review of the participant's prescribed treatment regimen with feedback on antiepileptic drug adherence over the past 2 weeks was provided at all the sessions. As described in Modi 2013, during sessions 2-4, families identified a specific antiepileptic drug adherence barrier and then a problem- solving exercise was conducted. Families generated potential solutions to overcome the barrier. Each family member participating in the session was required to rate each solution and a final solution was agreed on by the family. The written action plan provided a detailed solution with specifics regarding when, where, and how the new solution should be implemented. A behavioral contract outlining the action plan was signed by all participants of the problem-solving session. Between intervention sessions, the family was instructed to use the plan, and the interventionist contacted the family in between via telephone or email to provide continued guidance and support as the family implemented the action plan. This provided families the opportunity to fine-tune the solution or renegotiate a new solution if the solution identified in sessions 2-3 was not working well. A similar problem solving format was used for sessions 3-4, with a follow-up phone contact in between visits.

Modi 2016 notes that even young children were able participate in problem-solving sessions, although the extent of the engagement did vary depending on age. For example, the authors note, toddlers and preschool children could provide examples of rewards/reinforcers they liked and whether they liked possible solutions. In contrast, older children were more likely to provide viable solutions that families could choose and would often be involved in helping write these down and choose the solution.

\section{Strategies for teenagers and parents}

\section{Counselling programme based on video-conferencing for teenagers and their families}

During an initial assessment, a 90-minute video-taped family interview involved a series of open-ended questions about the nature of each family member's concerns (Glueckauf 2002). Five family counselling sessions of 1.5 to 2 hours then follow. Commencing around two weeks later, the primary function of the second session is to identify the priorities for counselling and to develop an initial treatment plan, focusing on two or three priorities for intervention. The following sessions are also typically at intervals of two weeks. The primary objectives of these sessions are to assist family members in attaining their specific counselling goals. Each session follows a similar format centred on the counselling goals. At the end of the fifth session, family members are asked to consider the option of pursuing further intervention (two additional sessions) or terminating the programme after the sixth session.

\section{Strategies for children, adolescents and their parents \\ FLIP\&FLAP programme}

The FLIP\&FLAP programme was developed following a three-stage process (Jantzen 2009). This process included in the first phase, qualitative interviews conducted with 7 children with epilepsy (aged 8 to 18 years) and their mothers and information about the most frequent questions and worries of parents and children being reported to the project team from epilepsy specialists. In the second phase, a training guideline was produced and piloted on a children's course, an adolescent's course and two adults' courses. From these pilot sessions, in the third phase, the curriculum of the programme was systematically developed using a formative evaluation of $37 \mathrm{children/}$ adolescents and 54 parents conducted in several north German clinics; the results of each evaluation were used to tailor the programme more closely to the needs of the participants and trainers.

The FLIP\&FLAP programme is a 2-day or a 2.5-day course, consisting of continuous sessions (14 hours and 16 hours, respectively) in which parents and children (aged 8 to 11 years) or adolescents (aged 12 to 16 years) are taught separately from one another in groups of 5-8 families. It consists of detailed manuals for trainers and a diverse range age-related teaching material so that participants can understand seizures better and develop a more adequate self-concept of the disease. This includes a film about seizures, two rag dolls called Flip and Flap, a game about epilepsy facts, a comic book for children and an information booklet for parents. Delivered by two trainers (healthcare professionals: nurses, social workers, doctors or psychologists), the courses include the following seven domains.

- Disease knowledge: understanding of the disease through information on the pathophysiology of the condition and treatment appropriate to participants' age and needs. 
- Disease-related emotions: discussion of shared emotions such as anxiety, guilt or embarrassment and coping strategies.

- Communication: dialogue among children, adolescents, parents and healthcare professionals is encouraged.

- Self-responsibility: children, adolescents and parents are encouraged to share responsibility for managing the disease, particularly to counteract parental tendency for overprotection.

- Self-management: children and adolescents are encouraged to be self-reliant, particularly in relation to taking medication and choice of leisure activities.

- Participation: families are encouraged to question their expectations of stigmatisation and to cope with aspects of the disease openly and confidently; children and adolescents are encouraged to participate socially.

- Educational insecurity: educational counselling and further information on diagnostic possibilities is provided for parents.

Central to the programme is the FLIP\&FLAP story. Using children's expressions and speech patterns, this story is of the teamwork that happens between the 'Flaps' (the 'clumsy' nerve cells) and the 'Flips' (the strong and fit colleagues of the 'Flaps'). The children's course deals with all contents through play. In the adolescents' programme, connections are made between the FLIP\&FLAP model and more scientific explanations of epilepsy through non-directive learning. Particularly for parents, illustrated exemplary case studies serve as stimulants for discussion and understanding.

\section{WHAT'S NEW}

\begin{tabular}{lll}
\hline Date & Event & Description \\
\hline 27 September 2016 & $\begin{array}{l}\text { New citation required but conclusions } \\
\text { have not changed }\end{array}$ & Conclusions are unchanged. \\
\hline 27 September 2016 & New search has been performed & Searches updated 27 September 2016; one new included study. \\
\hline
\end{tabular}

\section{H I S T O R Y}

Protocol first published: Issue 4, 2006

Review first published: Issue 12, 2010

\begin{tabular}{lll}
\hline Date & Event & Description \\
\hline 9 December 2013 & $\begin{array}{l}\text { New citation required but conclusions } \\
\text { have not changed }\end{array}$ & Conclusions remain the same. \\
\hline 9 December 2013 & New search has been performed & $\begin{array}{l}\text { Searches updated 9 December 2013; two new studies have been } \\
\text { included and the review has been extensively re-written by one } \\
\text { of the original authors (Peter Bradley) and a new author (Nigel } \\
\text { Fleeman). }\end{array}$ \\
\hline
\end{tabular}

\section{CONTRIBUTIONS OF AUTHORS}

$\mathrm{PB}$ and $\mathrm{BL}$ developed the protocol for this review and developed the final systematic review.

NF, PB and BL independently reviewed papers for inclusion using Cochrane EPOC Group criteria.

PB led the analysis of included papers.

$\mathrm{BL}$ wrote the original review, and NF wrote the updated reviews.

PB commented on and contributed to the write up of the original and updated reviews.

\section{DECLARATIONSOF INTEREST}

NF: none known. 
PB: none known

\section{SOURCES OF SUPPORT}

\section{Internal sources}

- No sources of support supplied

\section{External sources}

- National Institute of Health Research (NIHR), UK.

This review was supported by the NIHR, via Cochrane Infrastructure funding to the Epilepsy Group. The views and opinions expressed therein are those of the authors and do not necessarily reflect those of the Systematic Reviews Programme, NIHR, the National Health Service (NHS) or the Department of Health.

\section{DIFFERENCES BETWEEN PROTOCOLANDREVIEW}

PB was lead author on the protocol. Review methodology was unchanged from that included in the protocol.

\section{NDEX TERMS}

\section{Medical Subject Headings (MeSH)}

*Delivery of Health Care; *Self Care; Adaptation, Psychological; Controlled Before-After Studies; Counseling; Epilepsy [psychology] [*therapy]; Parents [ ${ }^{\star}$ education]; Patient Education as Topic [ ${ }^{*}$ methods]; Randomized Controlled Trials as Topic; Self Disclosure; Treatment Outcome

\section{MeSH check words}

Adolescent; Child; Humans 